Citation: $\quad$ Pons, D. (2010). System model of production inventory control. International Journal of Manufacturing Technology and Management (IJMTM), 20(No.1-4), 120 - 155.

PREPRINT VERSION. There may be small differences. For the paper as it finally appeared please see DOI 10.1504/IJMTM.2010.032895.

\title{
System model of production inventory control
}

Dirk Pons ${ }^{1}$

Christchurch Polytechnic Institute of Technology, PO Box 540, Christchurch, New Zealand, tel +64 3940 8127, fax+64 3940 8059, email ponsd@cpit.ac.nz or dirk@pons.ws

\section{Biography}

Dirk J. Pons, PhD, PrEng, MIPENZ has been head of the Engineering School at Christchurch Polytechnic Institute of Technology (New Zealand) since 1999. He has experience in commercial engineering design, research \& development, teaching, and management of education. His engineering expertise is in mechanical design, manufacturing, risk, reliability, finite element analysis, and biomedical engineering.

\begin{abstract}
The primary consequence of just-in-time (JIT) production is reduction of inventory. The associated benefit is (a) improved cashflow due to less financial resource tied up in inventory, and (b) less storage space required hence more productive plant area. Coupled with lean production and total quality management (TQM), it may also be possible to (c) improve worker productivity, (d) improve product quality, and (e) reduce production waste. Thus there are strong financial incentives to move to JIT/lean production. However, existing methods cannot adequately explain the causality that leads to failed (or successful) JIT implementations. While it is generally acknowledged that qualitative variables exist and affect success, there are no structured system models that accommodate the qualitative variables. This paper describes a fresh theoretical approach to examining the larger organisational factors in which inventory control systems are embedded. A structured descriptive system model for production inventory control is described, including base stock, conwip, kanban, and hybrid systems. The model was then interrogated to produce lists of tentative critical success factors for implementation of these strategies in JIT and lean production, and propose explanations as to why it succeeds or fails. This demonstrates that it is indeed possible to use descriptive modelling methods to explore the effectiveness of JIT and lean production systems.
\end{abstract}

Keywords: inventory; production; JIT; lean; system model; IDEFO; organisational

\footnotetext{
${ }^{1}$ Please address all correspondence to Dr Dirk Pons, School of Engineering, Christchurch Polytechnic Institute of Technology, PO Box 540, Christchurch, New Zealand, or email dirk@pons.ws
} 


\section{Introduction}

The key characteristics of an engineering production system are high quality, low cost, short production time. Early developments of the necessary production principles occurred in the USA in the period 18501950 by individuals such as Whitney, Taylor, Gilbreth, Ford, Deming, and Juran. Significant subsequent development occurred in Japan, involving individuals such as Ishikawa, Taguchi, Toyada, Ohno, and Shingo, and manufacturing organisations such as Toyota, eventually becoming disseminated to a wider audience and producing the methods of Toyota production system (TPS), statistical process control, total quality management, lean production, just-in-time (JIT), etc.

There is substantial overlap in the various concepts. For example, JIT is directed at minimising transitional inventory, typically by use of a card (kanban) control system. Doing so reduces waste by potentially (a) reducing cashflow tied up in transitional inventory, (b) reducing space required for storage of intermediate and finnished product, and (c) reducing the likelihood of accumulation of finished but obsolete final product. Similarly, lean manufacturing focusses on reduction of waste of all types (design time, production time, production resources, etc.) in the pursuit of providing value to customers, and thus includes JIT as a core concept. Thus, while lean production has been termed one of the 'most influential manufacturing paradigms of recent times' (Holweg, 2007, p420), and various 'mutations' of it continue to be developed (Lee \& Jo, 2007), it overlaps with many other quality methods. Both JIT and lean use continuous improvement (kaizen) methods to identify and implement changes. Both are interested in rapid changeover of production plant and small batch sizes (production levelling). Thus the JIT and lean concepts are entangled: they are dependent on each other, frequently implemented concurrently, and the precise meaning of the terms is blurred.

The purpose of this paper is not to disentangle JIT and lean production, but to examine a common component of both, namely production inventory control. Various control strategies are compared and contrasted, and critical success factors identified. In the process a novel theoretical conceptual model is developed.

\section{$2 \quad$ Existing models of lean production}

A large literature exists on JIT and lean manufacturing, characterised by several identifiable approaches. As will be shown, the present work takes a different and novel approach.

One common approach is based on case studies. There is a large practitioner literature which typically reports substantial improvements due to introduction of JIT and lean processes, e.g. reduction of inventory (SAP, 2004). Of course much of the practitioner literature is based on experience rather than research, and while useful has the risk of being commercially motivated. Other case studies are academically rigorous and more objective (e.g. Anderson, 1985; Leinonen, 1993; Mistry, 2005). Naturally the case study methodology is useful, but has the detriment that the results have limited ability to be generalised beyond the case (Mistry, 2005) because there are many unknown situational (i.e. contingency) factors. 
Other studies have been more statistically broad, sampling multiple organisations. For example, it has been found that ' $\mathrm{JIT}$ manufacturing at the plant level is associated with greater productivity in inventory usage ' (Callen, Fader, \& Krinsky, 2000, p277), thereby supporting the central premise that the method does indeed result in lean inventory. Others have found 'strong support for the influence of plant size on lean implementation, whereas the influence of unionization and plant age is less pervasive than conventional wisdom suggests' (Shah \& Ward, 2003, p129).

Another popular research approach is that of mathematical simulation of system dynamics. JIT is primarily a strategy to minimise inventory, and typically uses a kanban (card) system as the mechanism for achieving the necessary production control. Consequently JIT lends itself to a mathematical approach, and this has led to many simulation studies into the dynamics of control (e.g. Abdou \& Dutta, 1993; White, 1999), discrete events (Detty \& Yingling, 2000; Schroer, 2004), plant layout (Benjaafar, 2002), the optimum number of kanban cards (e.g. Aytug, Dogan, \& Bezmez, 1996; Fukukawa \& Hong, 1993), the effect of stochastic variation, perturbations of machine breakdown (Hu \& Meerkov, 2006), production smoothing (Caridi \& Sianesi, 2000), supplier economics (Golhar \& Sarker, 1992) and control strategies other than kanban (Huang \& Kusiak, 1998; Plenert \& Best, 1986; Selvaraj, Rao, \& Janardhan Reddy, 2003; Zapfel, 1998). Simulation of system dynamics is useful for better understanding the behaviour of such systems and assessing the effectiveness of changing system parameters (Lian \& Van Landeghem, 2007). In this way the mathematical simulation approach has advanced our knowledge of lean production systems and their optimisation. Nonetheless there are limitations. One is that, of necessity, the simulation studies are simplistic (e.g. in their treatment of line complexity and batch sizes), which usually limits their practical applicability. There is also the difficulty of capturing uncertainty in simulation models (Hajela \& Vittal, 2006). Also, unsteady conditions are common, e.g. in the construction industry (Walsh, Sawhney, \& Bashford, 2007). The problem with any demand-based production system is that the degree of production levelling depends 'critically on the accuracy of demand in the forecast' (Ackoff, 1981, p22). Corbett and Yucesan observed that most JIT simulation studies have important flaws, lack rigour in construction, produced questionable results, and could not easily be integrated together (Corbett \& Yucesan, 1993). Consequently, the purely mathematical approaches are often difficult to transfer into useful recommendations for practitioners, whereas in contrast the descriptive case-studies are readily applicable but of uncertain situational relevance.

As regards implementing lean systems, which is naturally important for practitioners, there is only a little research. An instrument exists for measuring the 'degree of leanness' (Soriano-Meier \& Forrester, 2002), various rules have been offered for implementing lean systems (e.g. Black, 2007), and stages suggested (Herron \& Braiden, 2006). But the problem remains that successful implementation of lean production is conditionally dependent on situational variables. As other authors have observed:

'The Hyundai case reveals that the adoption of TPS involves a complex evolutionary process of organizational learning and interpretation. This case sheds light on the possibility of various paths toward lean production, and demonstrates that both external and internal factors combine to form a complicated causal chain, influencing the 'mutated' emulation of TPS and generating a certain pattern of path-dependence in the evolutionary trajectory of a particular production model.' (Lee \& Jo, 2007)

Nor has the soft side been omitted as there are studies, though relatively scarce compared to the mathematical approach, on employee outcomes (Mehta \& Shah, 2005), human performance (Genaidy \& Karwowski, 2003), worker motivation (Schultz, Juran, Boudreau, McClain, \& Thomas, 1996), and union issues (Baird \& Lansbury, 1998). 
Critical success factors for successful lean production have been difficult to identify (Corbett \& Yucesan, 1993), and while some research exists (e.g. Keys, 1991; Koh, Demirbag, Bayraktar, Tatoglu, \& Zaim, 2007), the overall results have been inconclusive. Related to this is the problem of improving the effectiveness of existing lean systems, and adapting them to accommodate increased product variety (e.g. in the automotive industry Alford, Sackett, \& Nelder, 2000). Corbett and Yucesan believed that the primary means of improving JIT performance would be study of the environmental factors and not simulation of the kanban control system (Corbett \& Yucesan, 1993). However, identifying those factors is not easy. It is precisely the examination of the peripheral factors that forms the scope of the present work.

Whether JIT and lean production systems have detriments is a topic that has received little attention (Keys, 1991). It has been observed that 'the JIT method needs very committed workforce, integrated suppliers and flawless synchronization among all departments in the supply chain' (Leclair, 2005, p24), which in turn suggests that these might be constraining factors. There is also evidence that some organisations continue to struggle to implement lean production (Naim, Childerhouse, Disney, \& Towill, 2002). Furthermore, some authors have detected stagnation in the area:

'Despite the increasing application of just-in-time (JIT), lean and agile practices and new information systems that increase the visibility in supply chains, a lot of problems still remain. Surveys among European companies indicate that no significant improvements have taken place in delivery performance during last decade.' (Kaipia, Holmstrom, \& Tanskanen, 2002, p17)

Perhaps the most worrying of all is the risk of a 'lack of a scientific foundation for lean manufacturing' (Houshmand \& Jamshidnezhad, 2006, p13). In particular while much research focusses on the parts of the enterprise ('cellular level'), the need has been identified to improve the whole of the organisation (Tyler \& Cathcart, 2006).

To sum up, there is a need to develop a theoretical foundation for JIT and lean production, one that extends beyond mathematical simulation of the production itself, but instead captures the wider set of factors that determine production success. This is more than just optimising the number of kanbans or the plant layout, but extends to human factors that arise within the organisation, and situational variables imposed by the external environment. To put it another way, optimising the mechanical variables of production is futile if the organisation itself (or its environment) is not conducive to lean production. This problem is not addressed by most of the existing research approaches to lean production. Neither the case history or the simulation components of the literature can adequately explain the general causality that leads to failed (or successful) implementations.

While it is generally acknowledged that qualitative variables exist and affect JIT and lean success, there are no system models at the organisational level that accommodate these variables. If such models could be developed, they have the potential to explain causality, and thereby inform the design of production processes. It will likely take many iterations and multiple authors to achieve such an outcome, but it is worth making a start in this new direction of research because of the potential benefit in designing such production systems.

The objective of the present work was therefore to develop a candidate system model for production inventory control, one able to accommodate qualitative variables, capture the complex interaction of these variables in JIT and lean production systems, and tentatively identify critical success factors from a practitioner perspective. The area under examination is production of assembled physical artefacts, i.e. 
manufacturing industries such as those for dishwashers and motor vehicles, rather than service or software or other production processes.

\section{$3 \quad$ Method}

The selected method was a structured, deductive process to decompose the process (in this case the inventory control systems) into multiple sub-activities (functions), and for each deduce initiating events, the controls that determine the extent of the outputs, the inputs required, the process mechanisms that are presumed to support the action, and the outputs. Descriptive consistency was enforced between objects (arrows) and associated activities (blocks). The resulting model was expressed graphical as a series of flowcharts using the integration definition zero (IDEFO) notation (FIPS, 1993; KBSI, 2000). It was then inductively reconciled with existing literature and research. This involved successive refinement, even redefinition, of the model.

The work has a precursor in that other authors have applied IDEF0 to specific case studies (Gingele, Childe, \& Miles, 2003). While they did not create a generic model, they did identify lists of factors for inclusion in ISO 9001 compliant production processes, which have been used to inform the present work.

Other authors have used IDEF for theoretical simulation studies (Huang \& Kusiak, 1998), but the IDEF3 format as opposed to the IDEFO format used here. IDEF3 is a logic block diagram approach using 'and' and 'or' type junctions, and is thus suitable for quantitative simulation proposes, whereas the present analysis explores the qualitative aspects.

\section{$4 \quad$ Results}

The results are a series of diagrams of the production process. The graphical notation supports four types of object variable: inputs, controls, outputs, and mechanisms (ICOM). These are distinguished by placement relative to the box (function or activity) with inputs always entering on the left, controls above, outputs exiting at right, and mechanisms below. It is important to note that arrows should be interpreted as conveying objects to activities (blocks) and not as sequence. An activity may begin autonomously when its required inputs are available and its constraints permit. Consequently, multiple activity boxes (e.g. production processes) can be simultaneously active (i.e. concurrent or parallel) and at different stages of completeness. Sequenced activities (series) can still be readily modelled where necessary. This provides the necessary functionality to model complex processes, which are otherwise difficult to model with conventional schematic diagrams.

The diagrams follow, with brief explanatory captions. The description of the models is straight forward and not described here, but the interested reader is referred to Appendix A for additional details. 


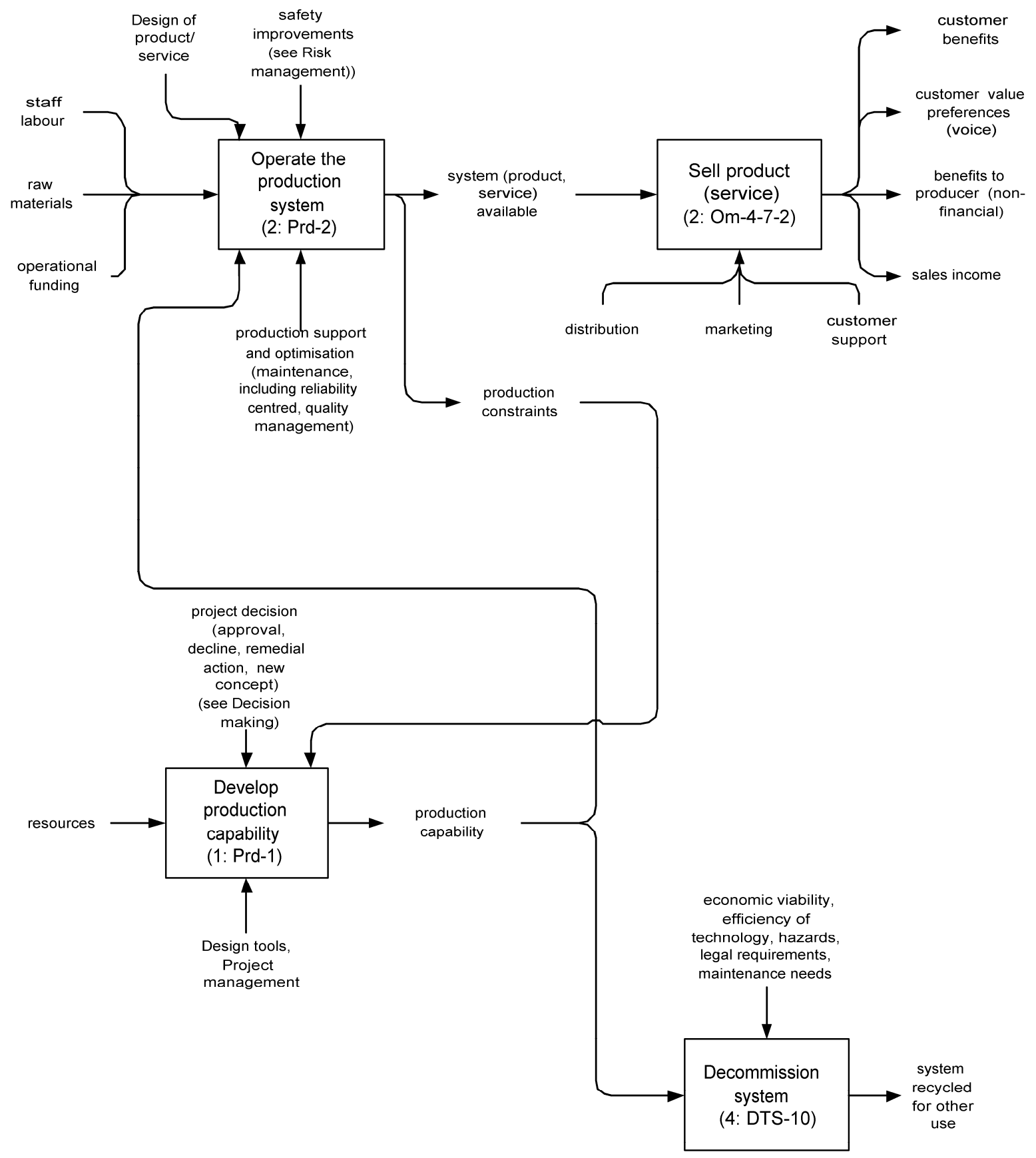

The top level of the model is shown here, wherein the activities are to develop production capability (1), operate the system (2), and deliver the product (or service) to the customer (3). There is also a fourth activity of decommissioning the production system (4) at the end of its life or the product life. The emphasis here is on the ways of operating the system (2)

\section{Produce product/service}




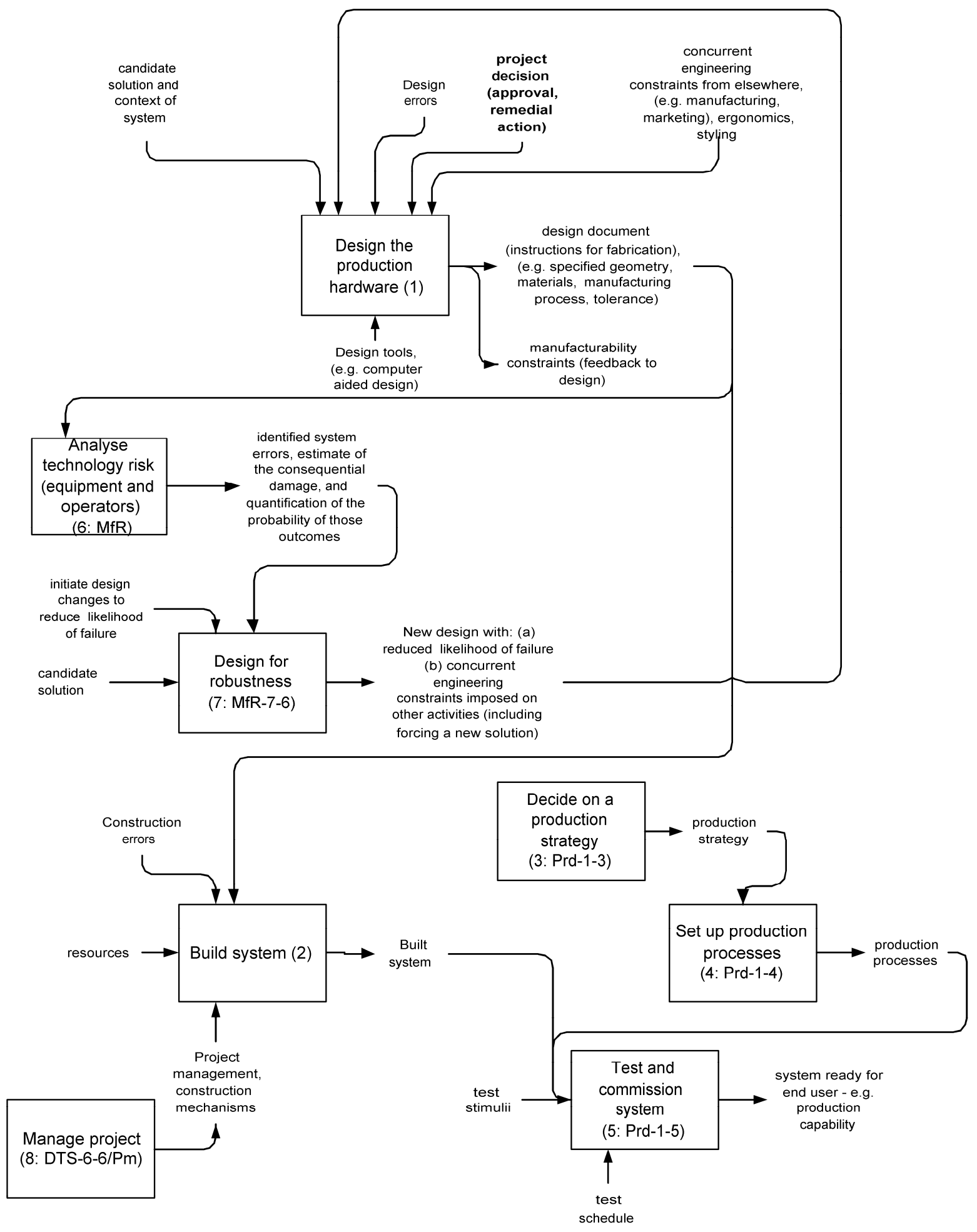

The first task is to design the production system (1). Thereafter the system may be built (2). It is also necessary to set up the production processes (4), which requires decision-making about the production strategy (3) to be followed. Finally the system is commissioned for use (5). In the process it is generally necessary to analyse the risks introduced by equipment and operators (6) and design for robust production processes (7). The construction is typically achieved using project management (8).

Develop production capability (Prd-1) 


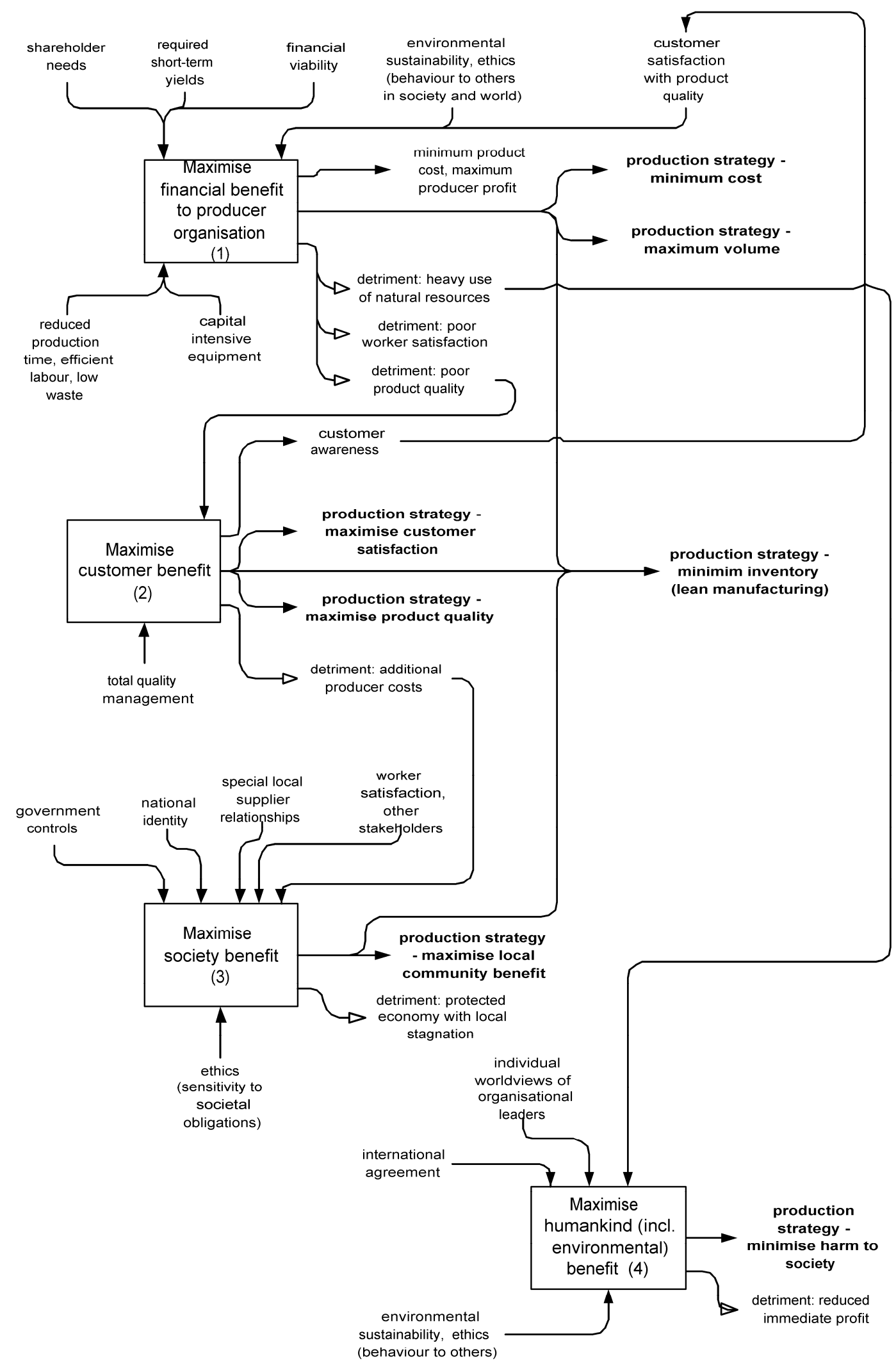

Decide on a production strategy (Prd-1-3) 


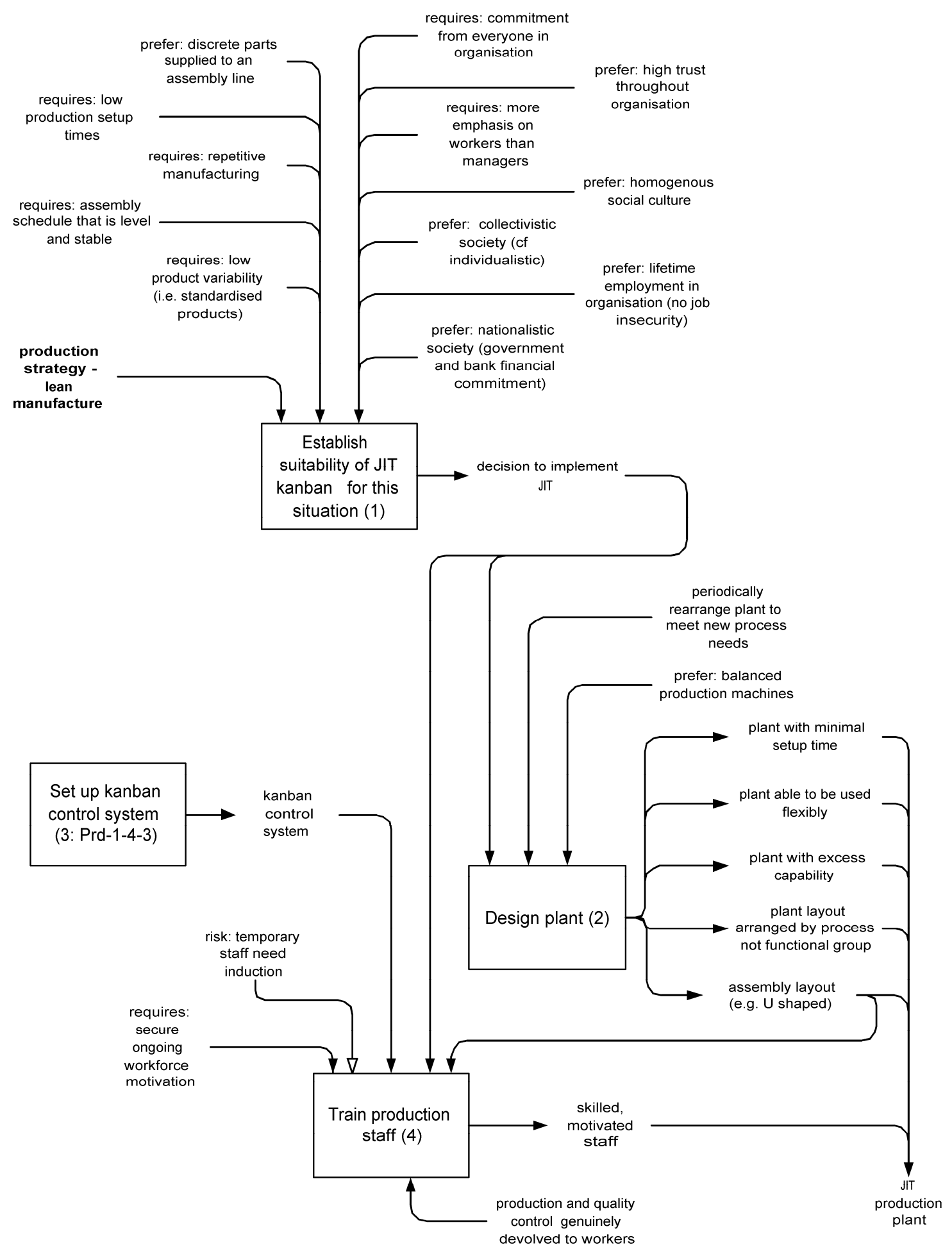

The first activity is to establish suitability of JIT for this situation (1). Once a decision is made to implement JIT, the next activity is to design the plant (2) to provide the features required for successful JIT. An important feature is that the plant should be arranged by process or product line, not functional group. It is also necessary to set up the kanban control system (3) (see Figure Prd-1-4-3) and train production staff (4).

\section{Set up production processes}




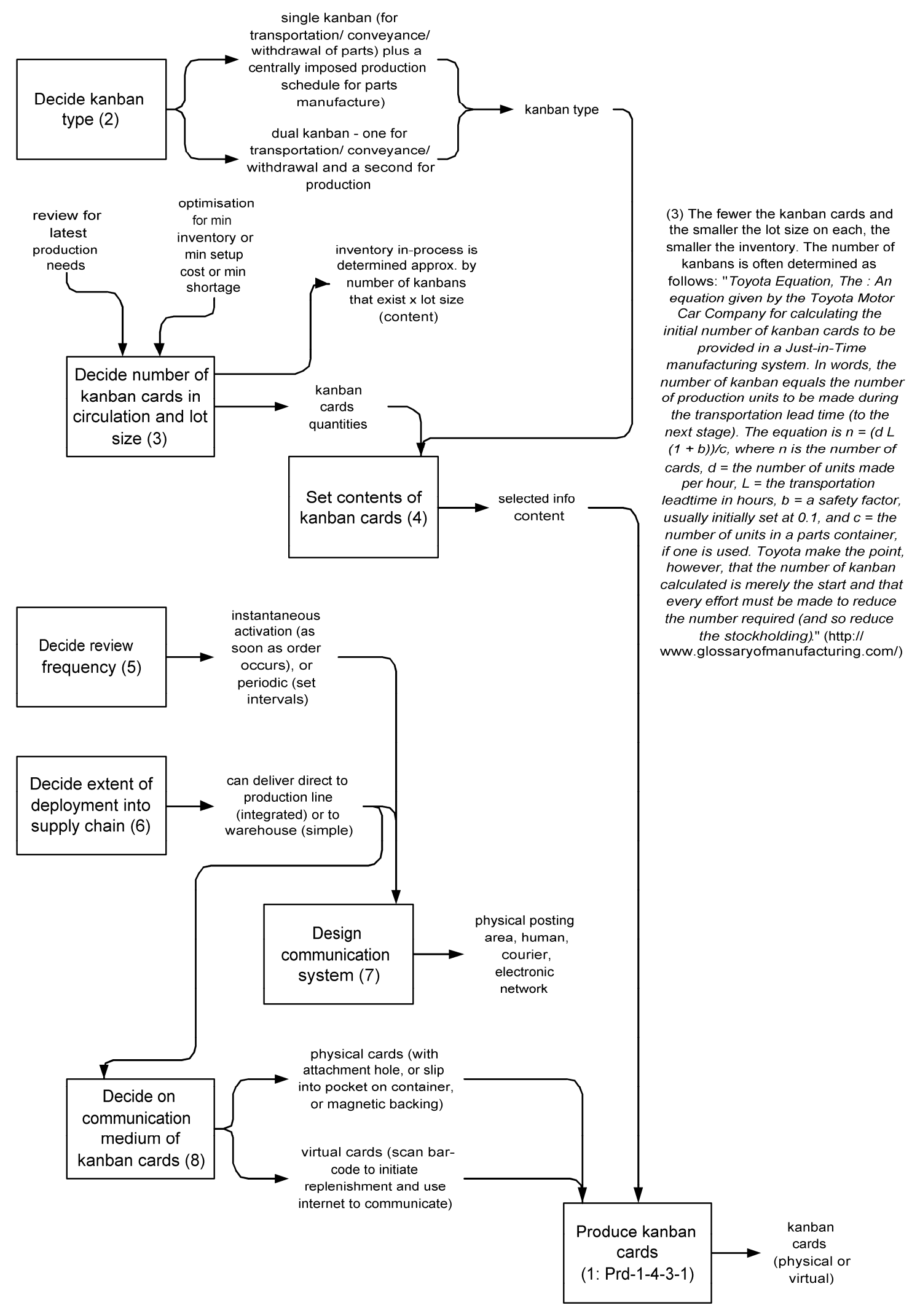

Set up kanban system (Prd-1-4-3) 


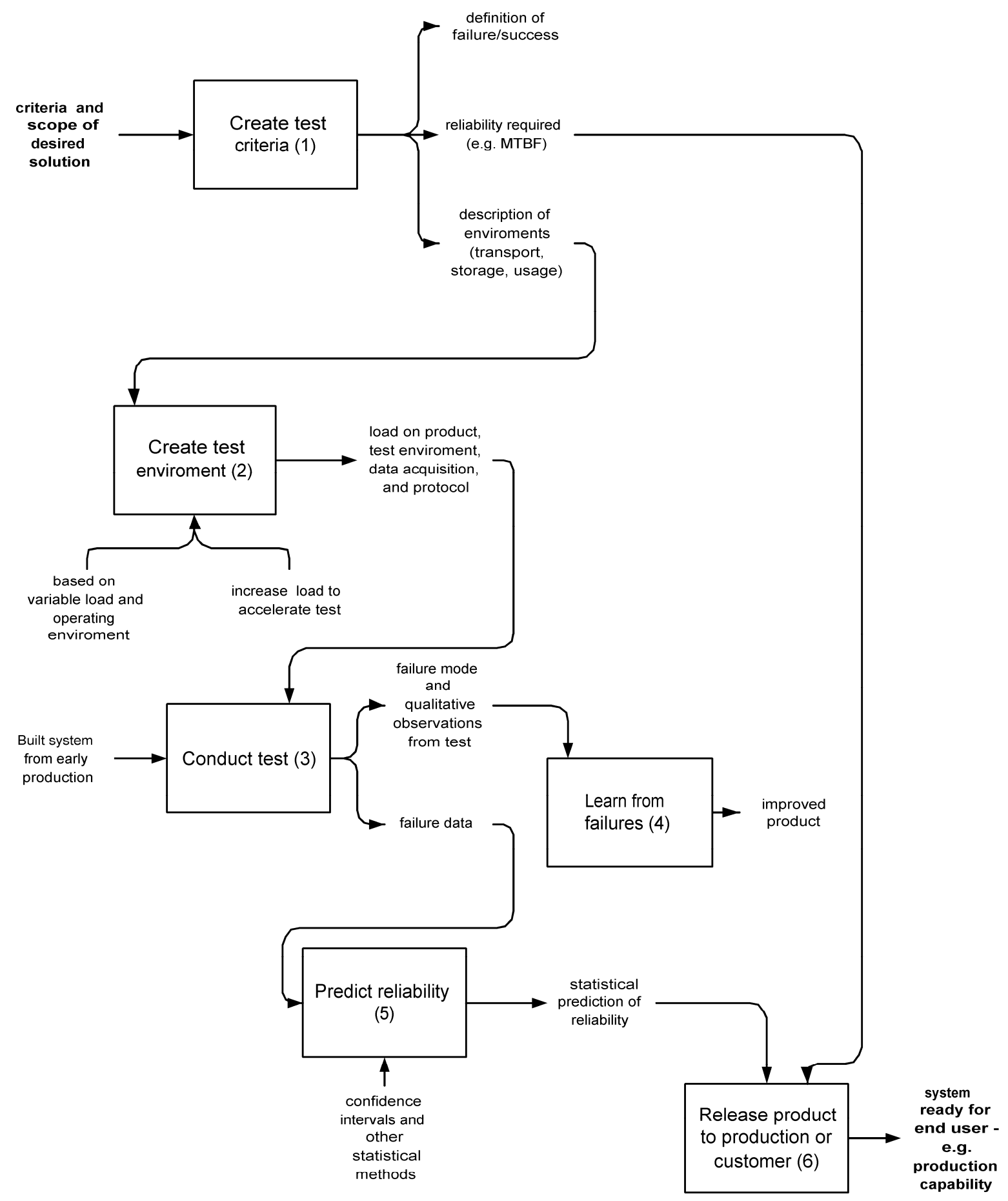

Test and commission system (Prd-1-5) 


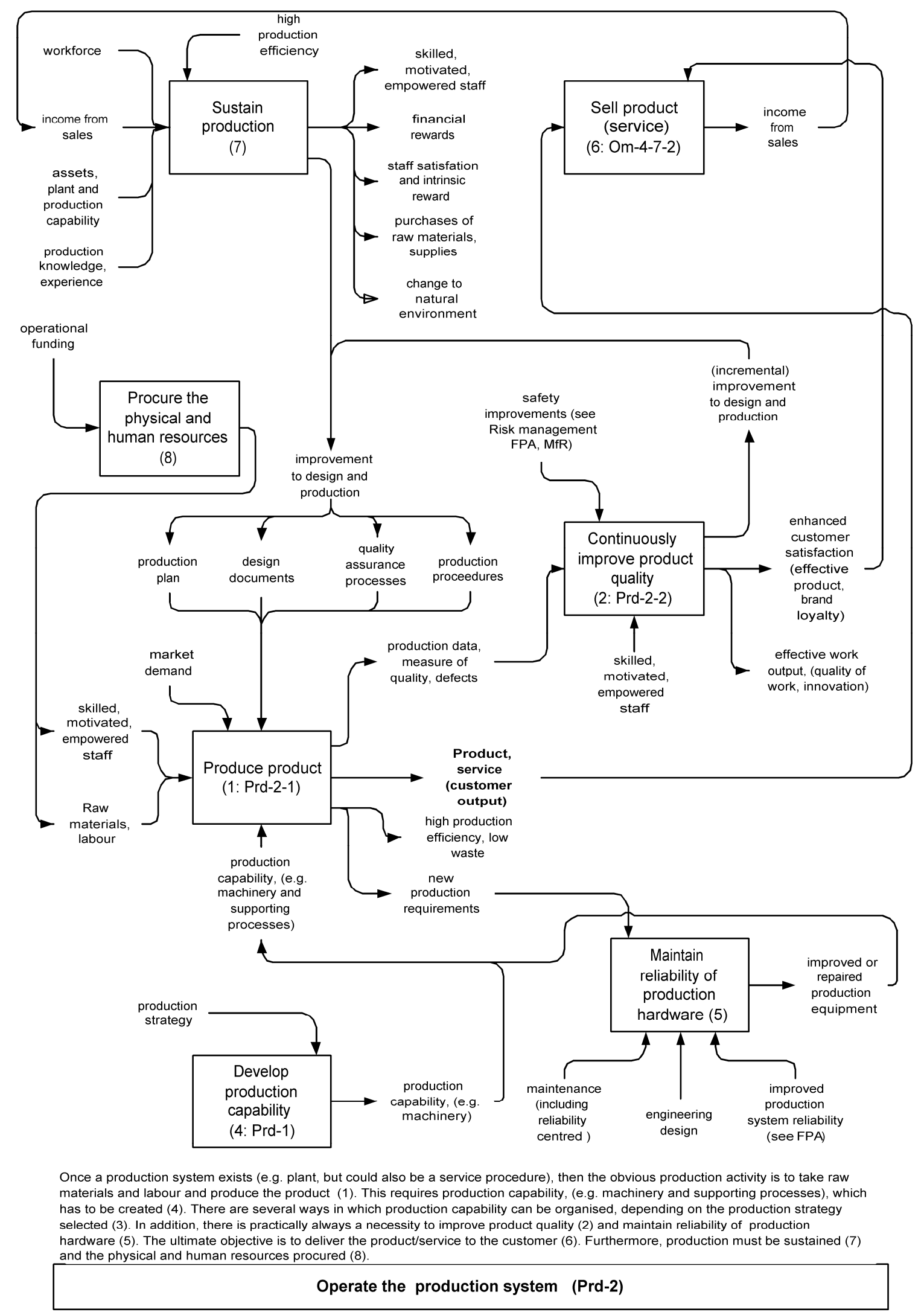




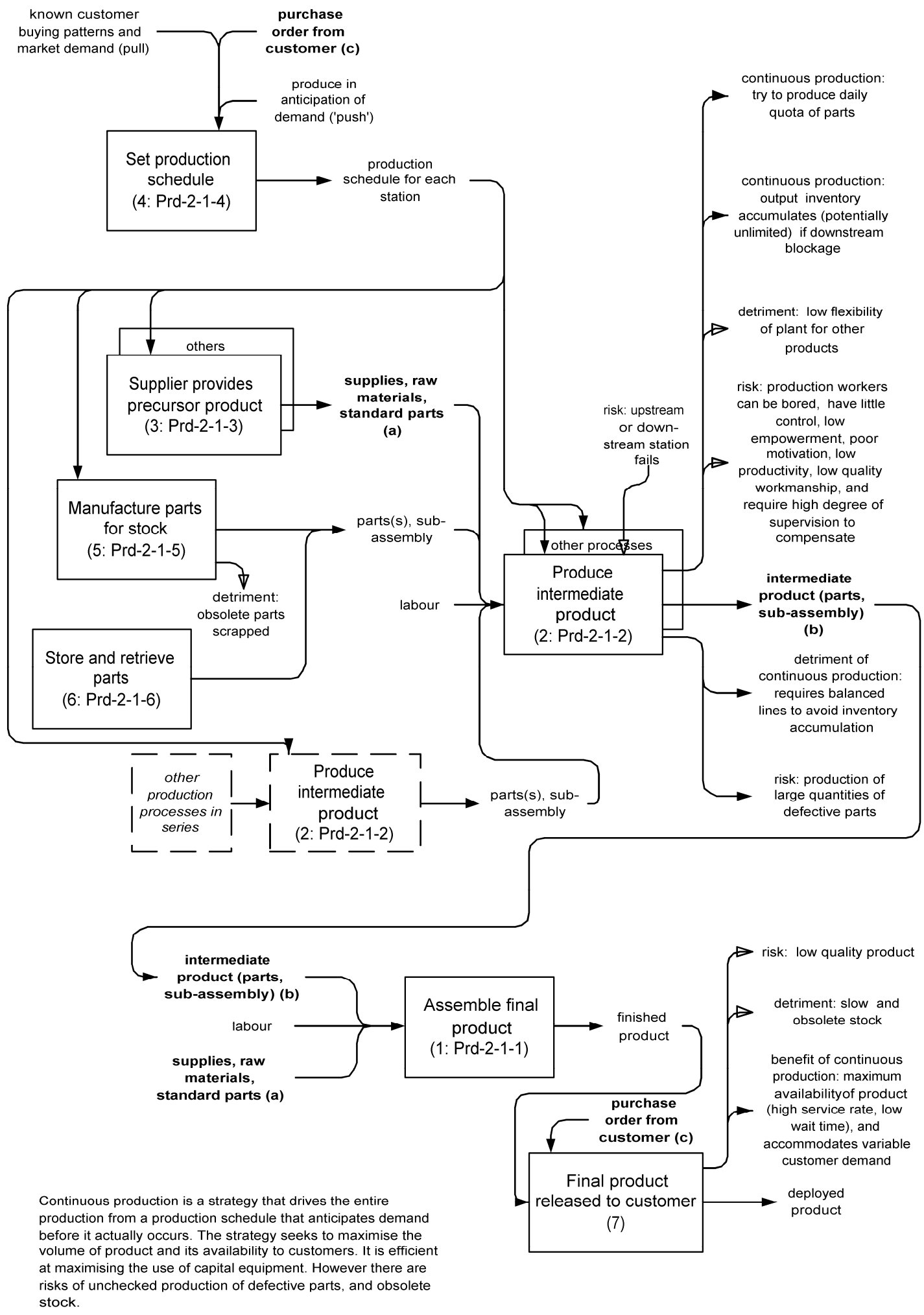

Produce product (Prd-2-1) A: Continuous 


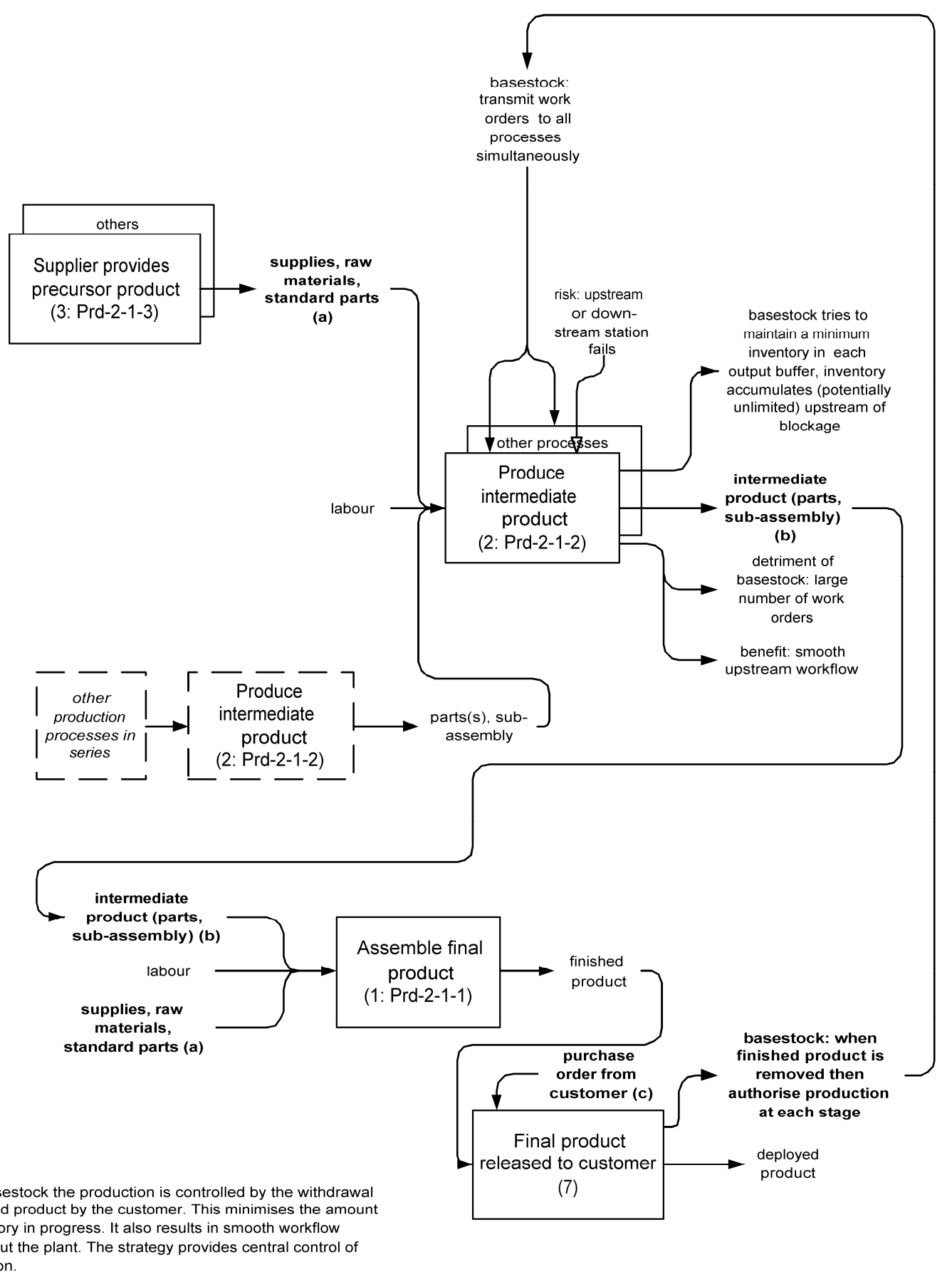

Produce product (Prd-2-1) B: Basestock 


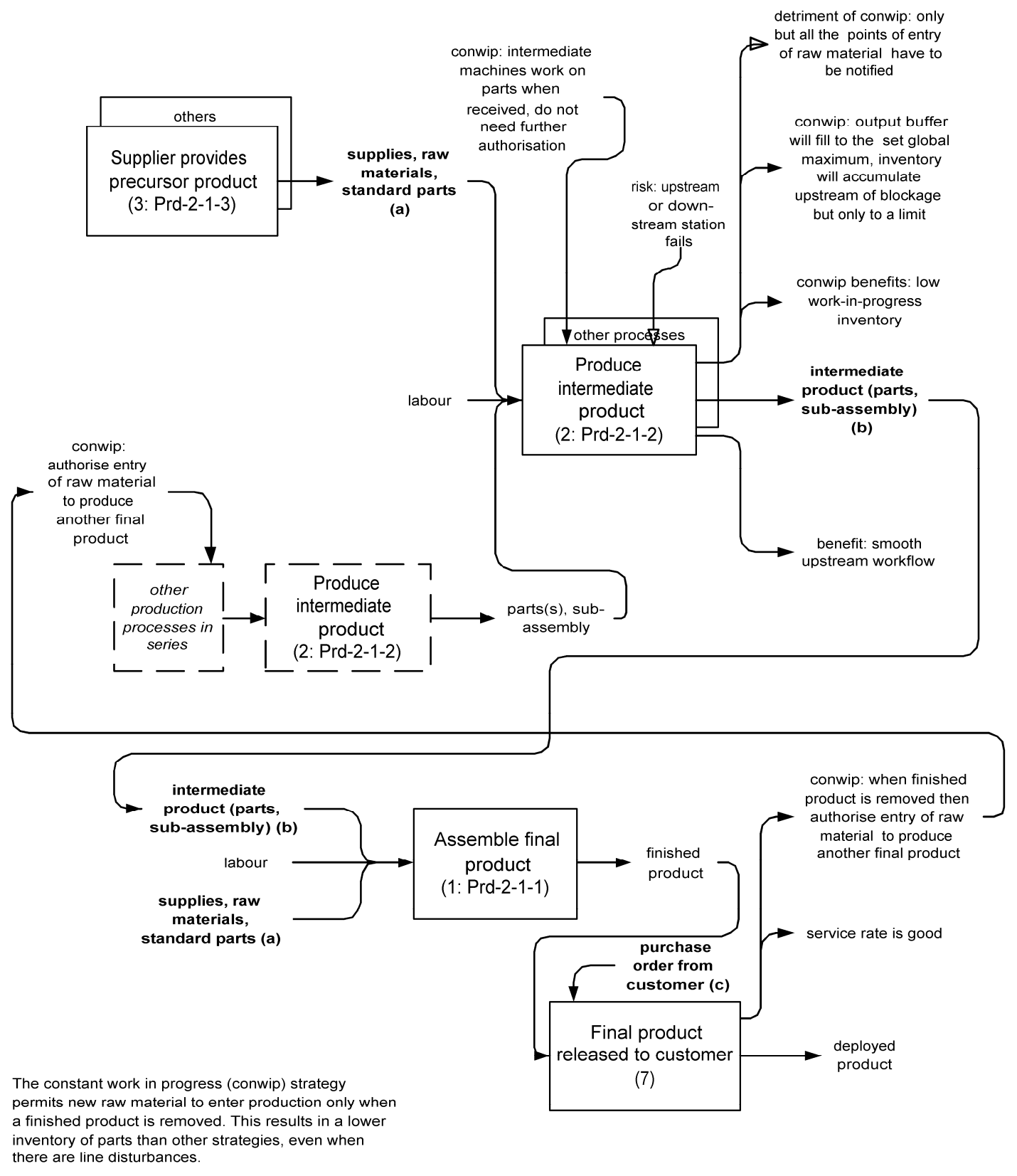

Produce product (Prd-2-1) C: Conwip 


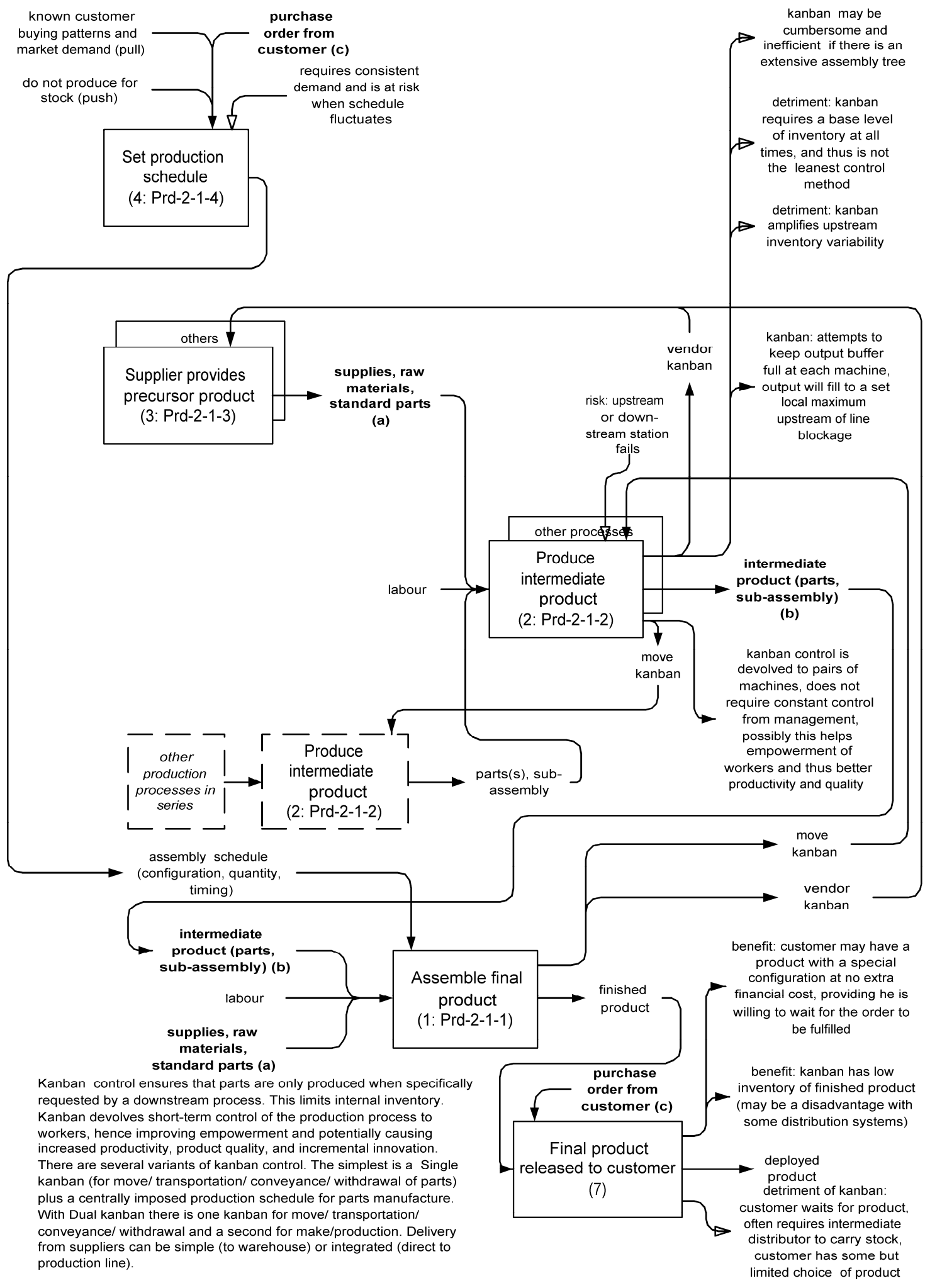

Produce product (Prd-2-1) D : Kanban 


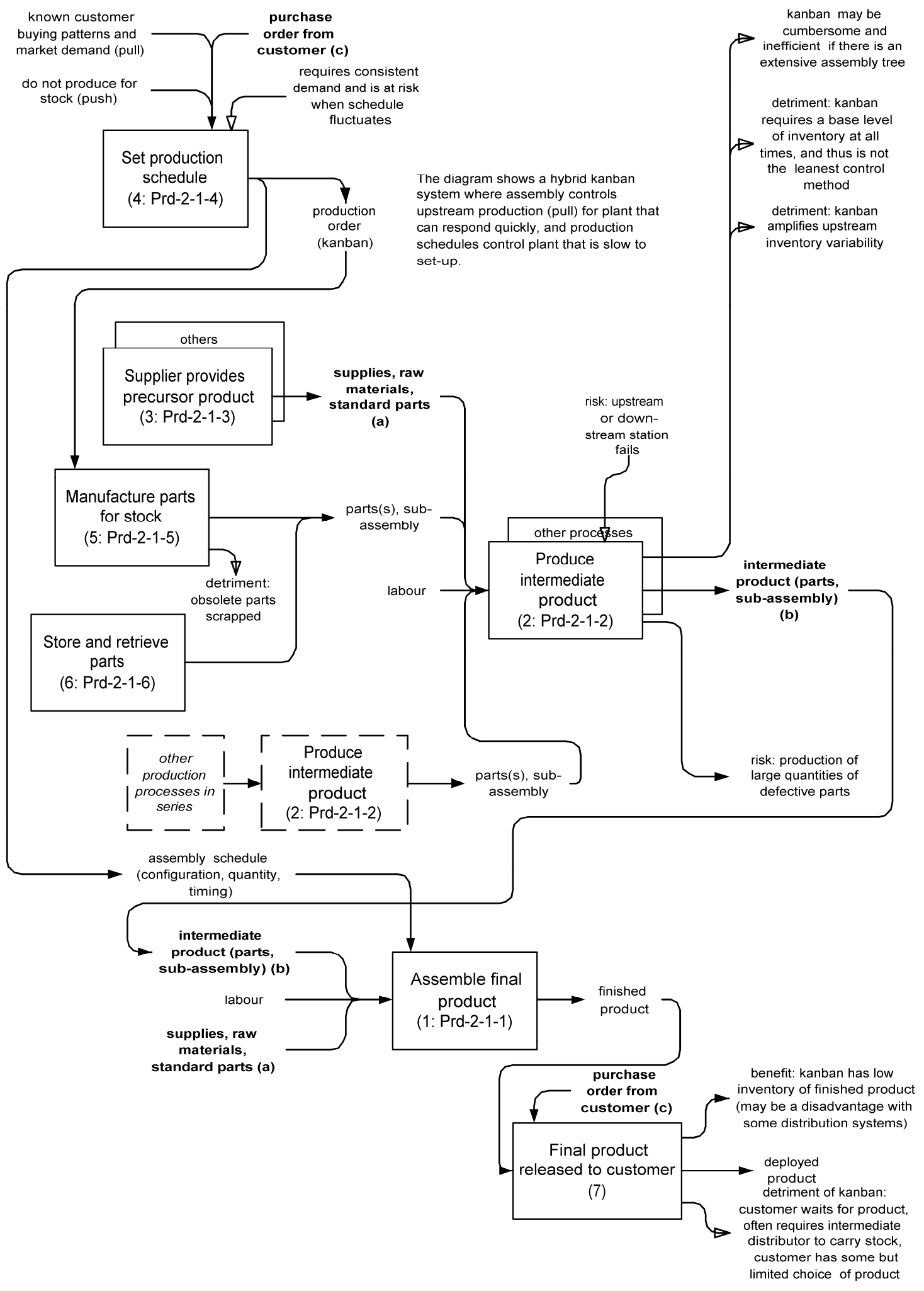

Produce product (Prd-2-1) E: Hybrid kanban + stock 


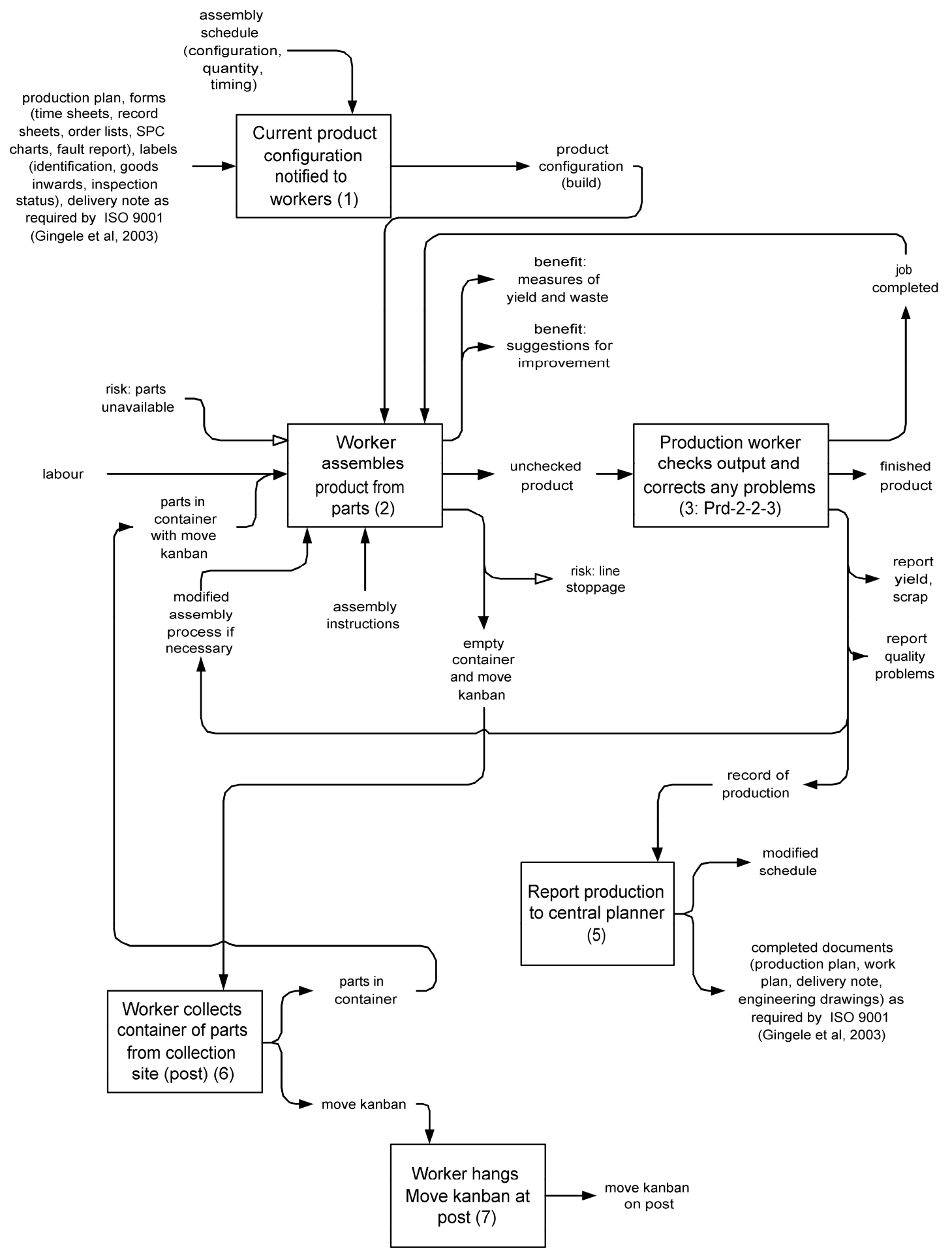

The assembly process, particularly for kanaban, is shown here. The initiating activity is for the central planning/sales department to advise the production staff of the required product configuration (1), and quantities thereof, usually on a daily (or shift) basis. This may be communicated electronically or by means of a notice board. Next the worker assembles product from parts (2), and then checks the output and corrects any problems (3). Production volumes and any problems are reported (5). Yield and wastage is also reported. Then the worker assembles the next product, which could be a different configuration. The worker collects a fresh container of parts from a collection site (post) (6) when the container of parts is exhausted at the assembly line. The exhausted move kanban is hung at the post (7), which physically alerts the materials handler to the need for replenishment.

\section{Assemble final product (Prd-2-1-1): Kanban}




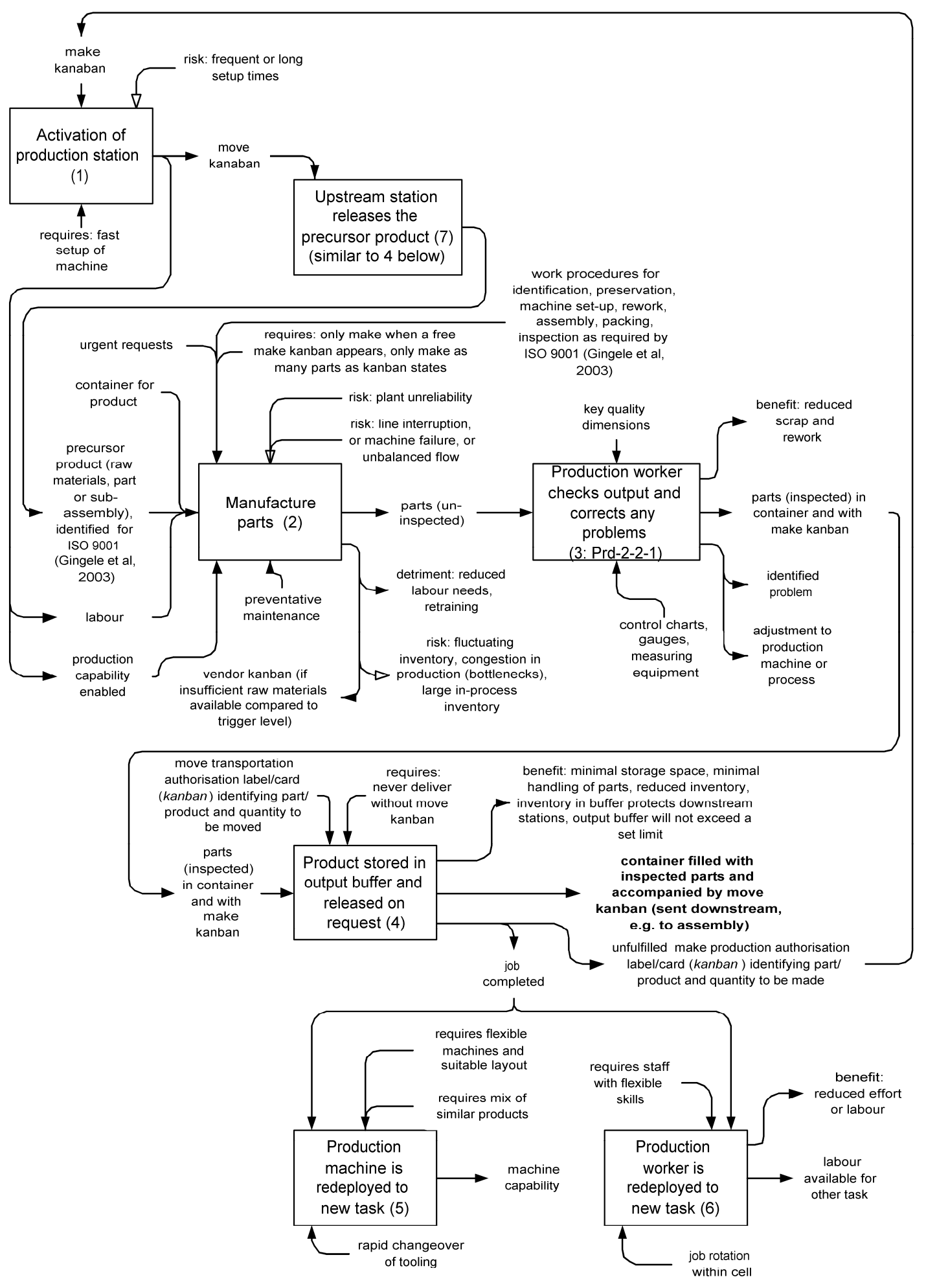

Produce intermediate product (Prd-2-1-2): Kanban 


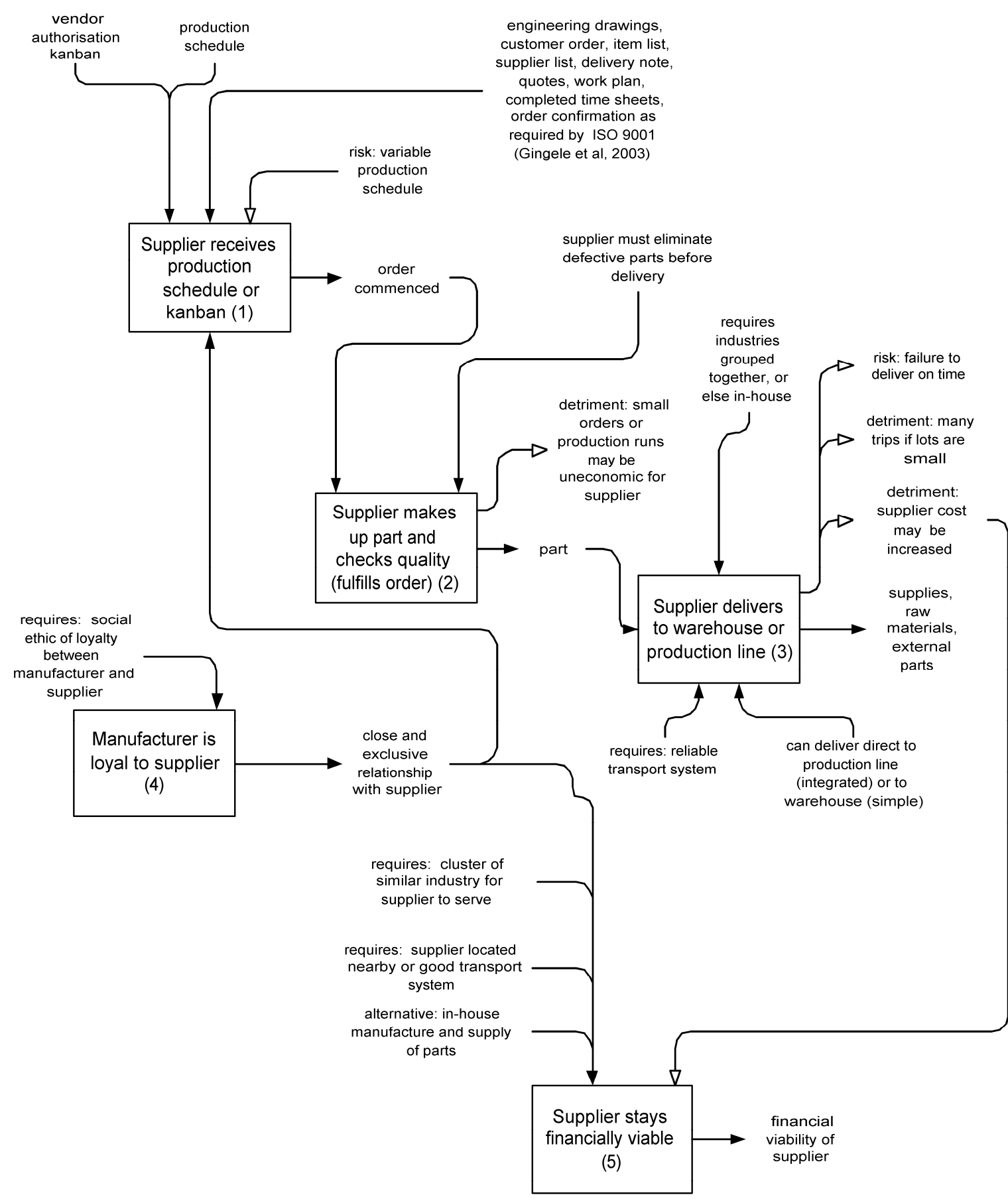

The process for supplying parts and raw materials just-in-time is shown here. Not all organisations deploy JIT to this extent. The process requires the production of a vendor kanban, which the supplier collects or receives (perhaps electronically) (1). The Supplier makes up the part and checks quality (fulfills order) (2), and then delivers it to the warehouse or production line (3). From the supplier's perspective, this system has some detriments: small orders or production runs, many trips if lots are small, and supplier cost may be increased. For the supplier to stay financially viable (5) requires a close relationship of loyalty from the manufacturer (4). It also requires a cluster of similar industry for the supplier to serve, and proximity of the supplier to the assembly line (or good transport system). Not all geographical regions provide these, so supplier viability may be difficult. An alternative is in-house manufacture and supply of parts. 


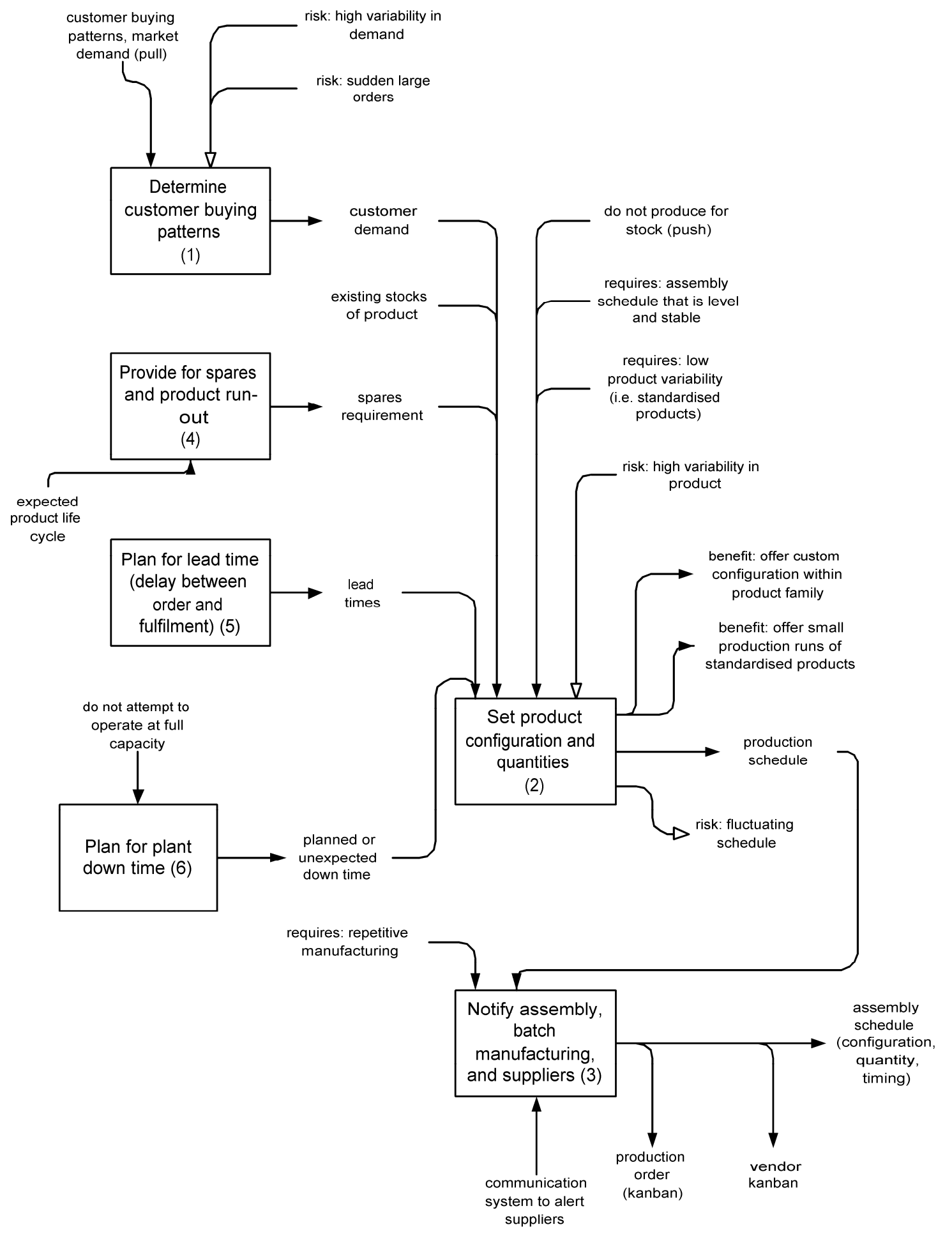

Setting product configuration and quantities (2) requires known customer buying patterns (1). It is also necessary to provide for spares and product run-out (4), and plan for lead time (delay between order and fulfilment) (5). Furthermore, JIT systems are at risk of becoming inefficient when attempting to operate at maximum production volume, because of the effects of congestion at certain points

(bottlenecks), machine unreliability, and other disturbances. Instead it is advisable to plan for plant down time (6) in the schedule. The production schedule results in the issue of the assembly schedule (to the assembly line), and production and vendor kanbans.

Set production schedule (Prd-2-1-4): Kanban 


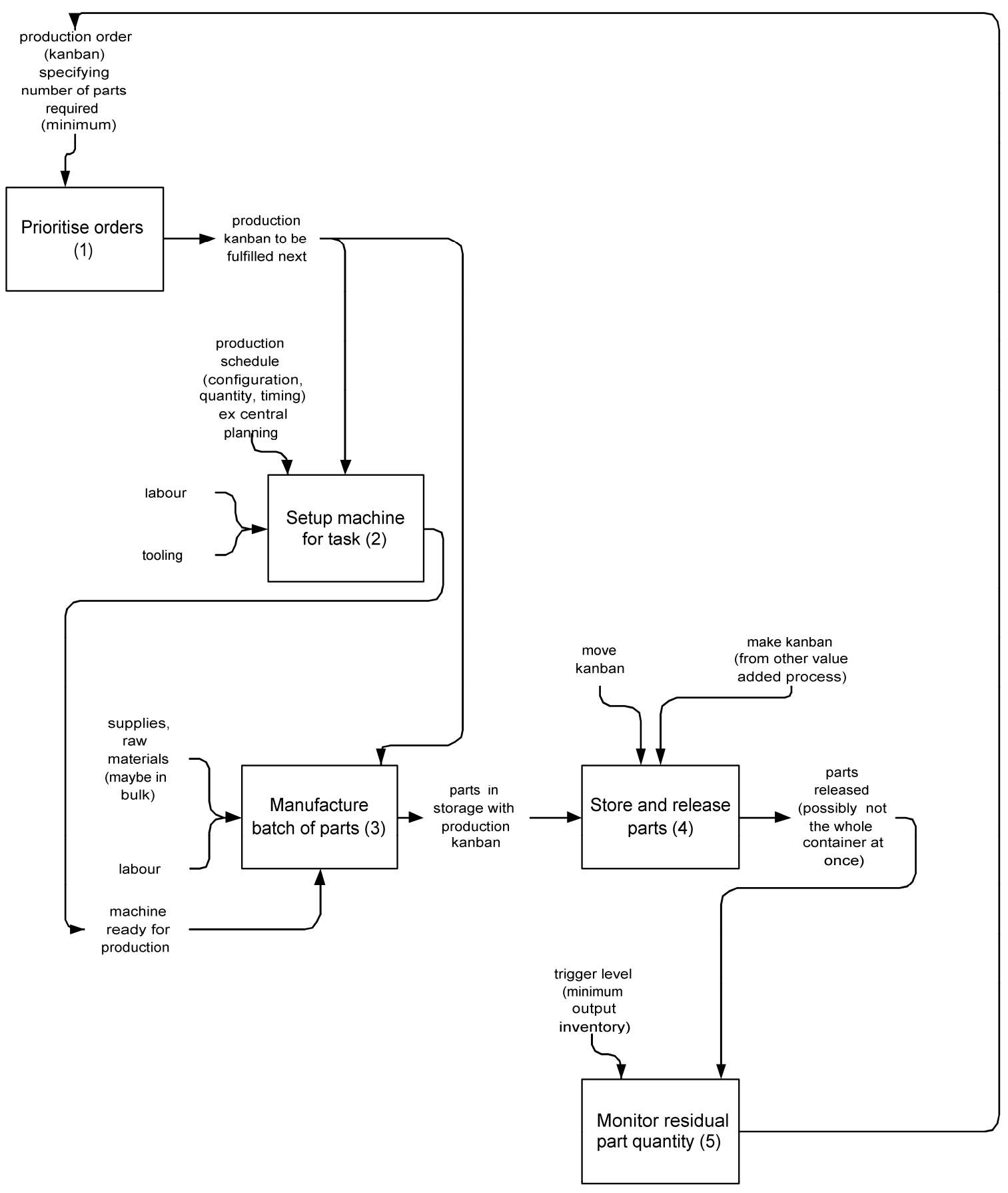

It is often impractical to deploy JIT to every part of the production system, in which case it is necessary to manufacture parts for stock. Production orders are used (these may be a type of kanban), specifying the number of parts required. These are prioritised (1), and once activated the machine is setup for the task (2), which may take some time, and the parts are manufactured (3). The parts are stored with their documentation (e.g. production kanban). This storage may either be local to the production station, or in a central location. This part of the production process is pushed rather than pulled. The parts may then be released incrementally, not necessarily whole containers at a time as with pure kanban. A move kanban may be used to trigger release. The residual part quantity is monitored (5), and when it goes below a minimum level (trigger level), then further production is initiated, e.g. by releasing the production kanban. 


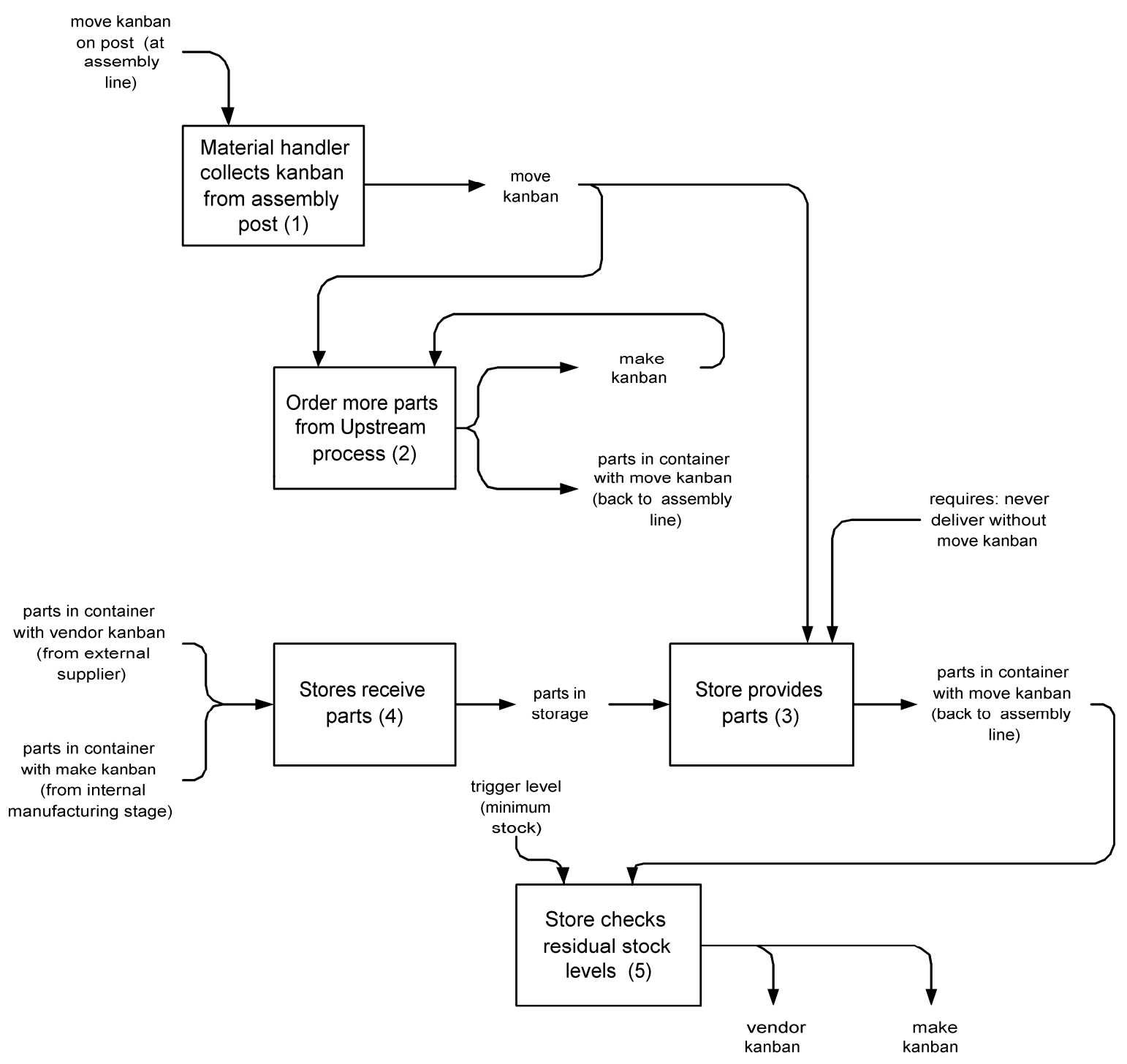

The hybrid production strategies provide for the storage and retrieval of parts. The material handler collects move kanbans from the assembly post (1), and then either collects more parts from an upstream JIT process (2), or the store provides the parts (3). The parts in the store could have come from an external supplier (see Figure Prd-2-1-3) or a non-JIT production process (see Figure Prd-2-1-5). The Store checks residual stock levels (5) against set trigger levels and reissues make- or vendor-kanbans as necessary to replenish stock. Thus there is no practical or conceptual difficulty in combining JIT pull and conventional push production processes. 


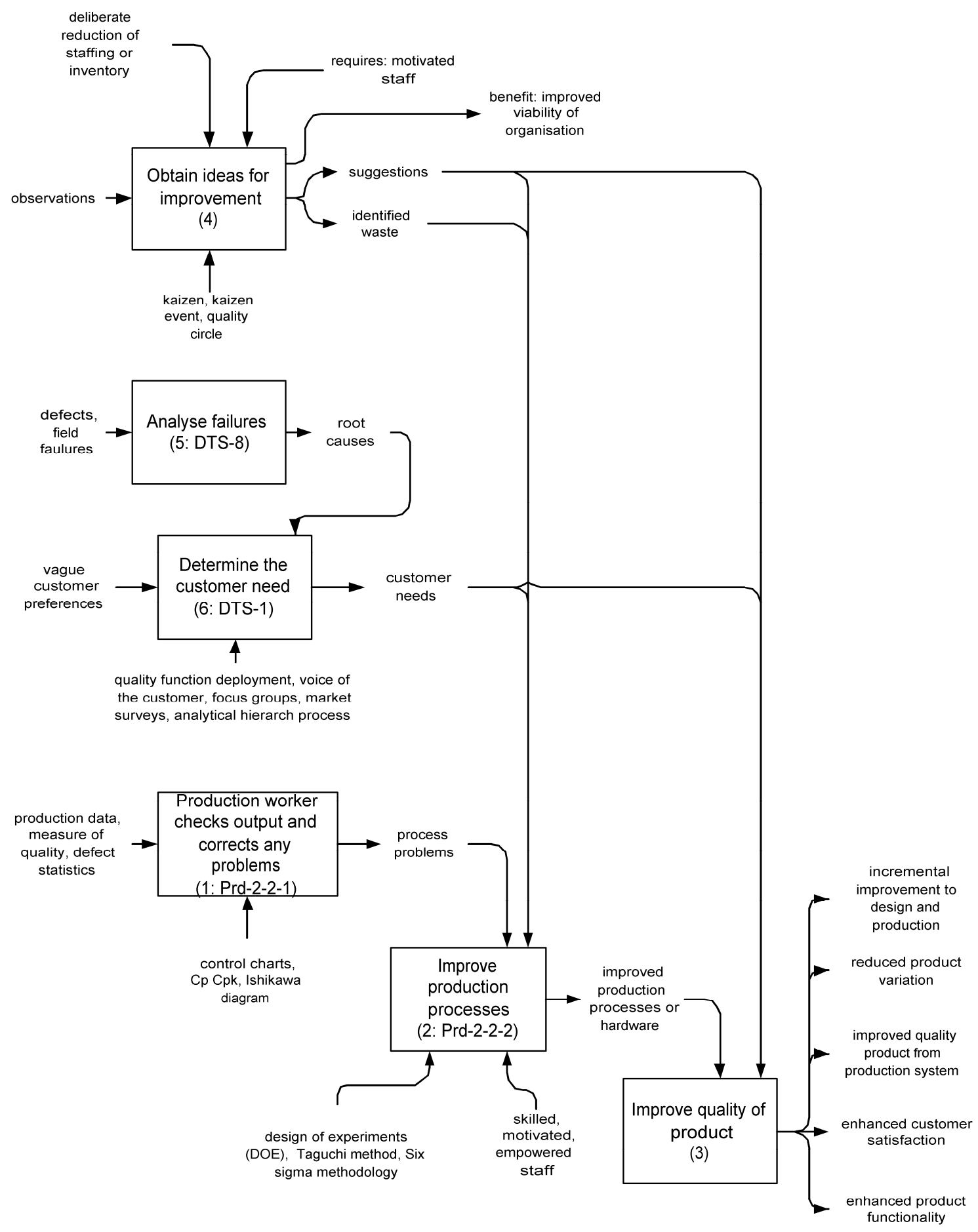

Organisations frequently integrate total quality management (TQM) and a JIT production system. A key activity in TQM is incremental improvement of the product and its production process (1), which requires obtaining ideas for improvement (4), analysing failures (5), and determining the customer need (6). Another important activity is for the production worker to immediately check the output (1) against

known key quality target dimensions (see Figure Prd-2-2-1 for details). Kanban in particular provides worker empowerment in the form of devolved control over production, so it integrates readily with TQM. If problems are detected then it is necessary to improve the production processes (2), and one method, namely the six sigma method, is detailed in Figure Prd-2-2-2.

Continuously improve product quality (Prd-2-2) 


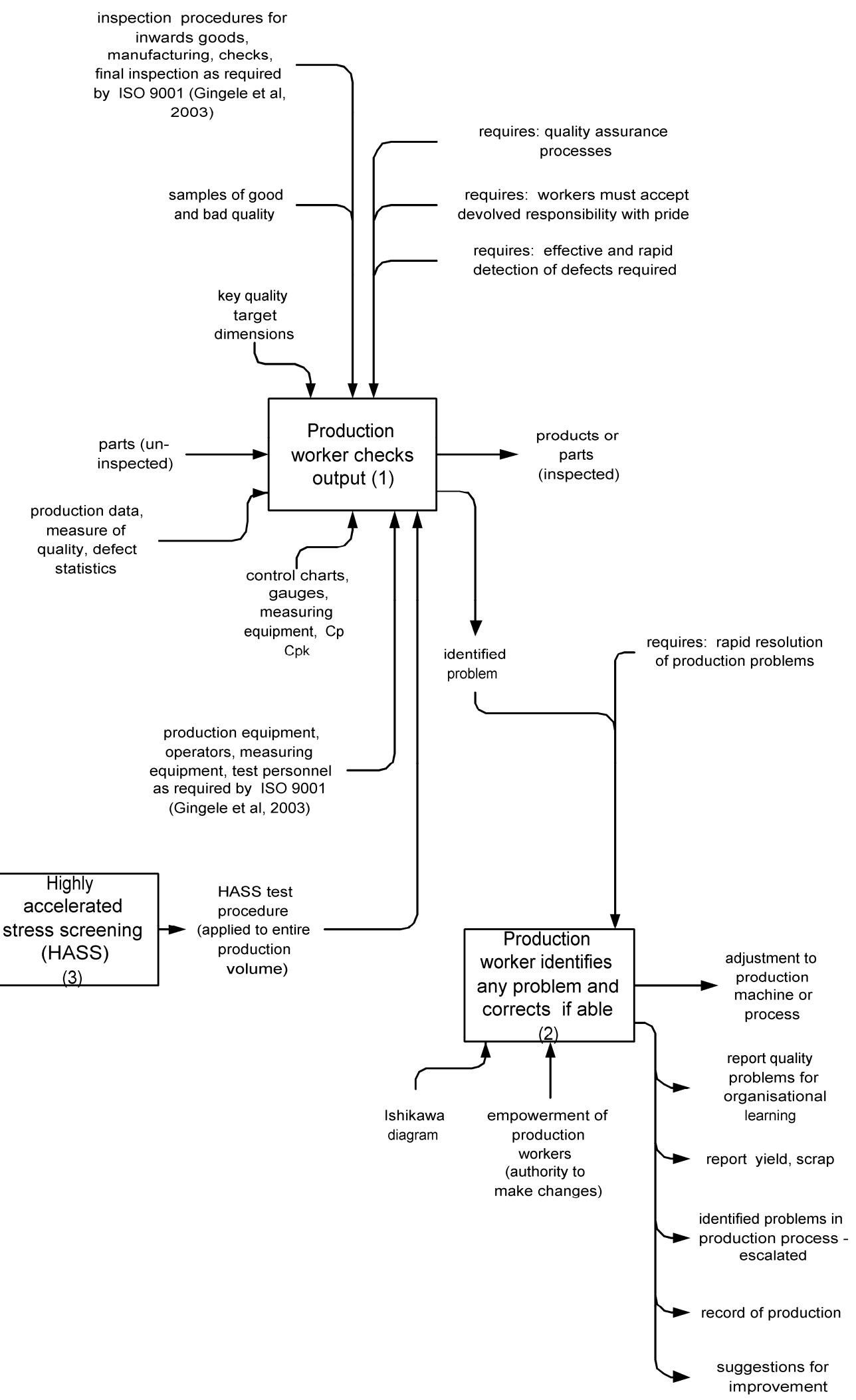

Production worker checks output and corrects any problems (Prd-2-2-1) 


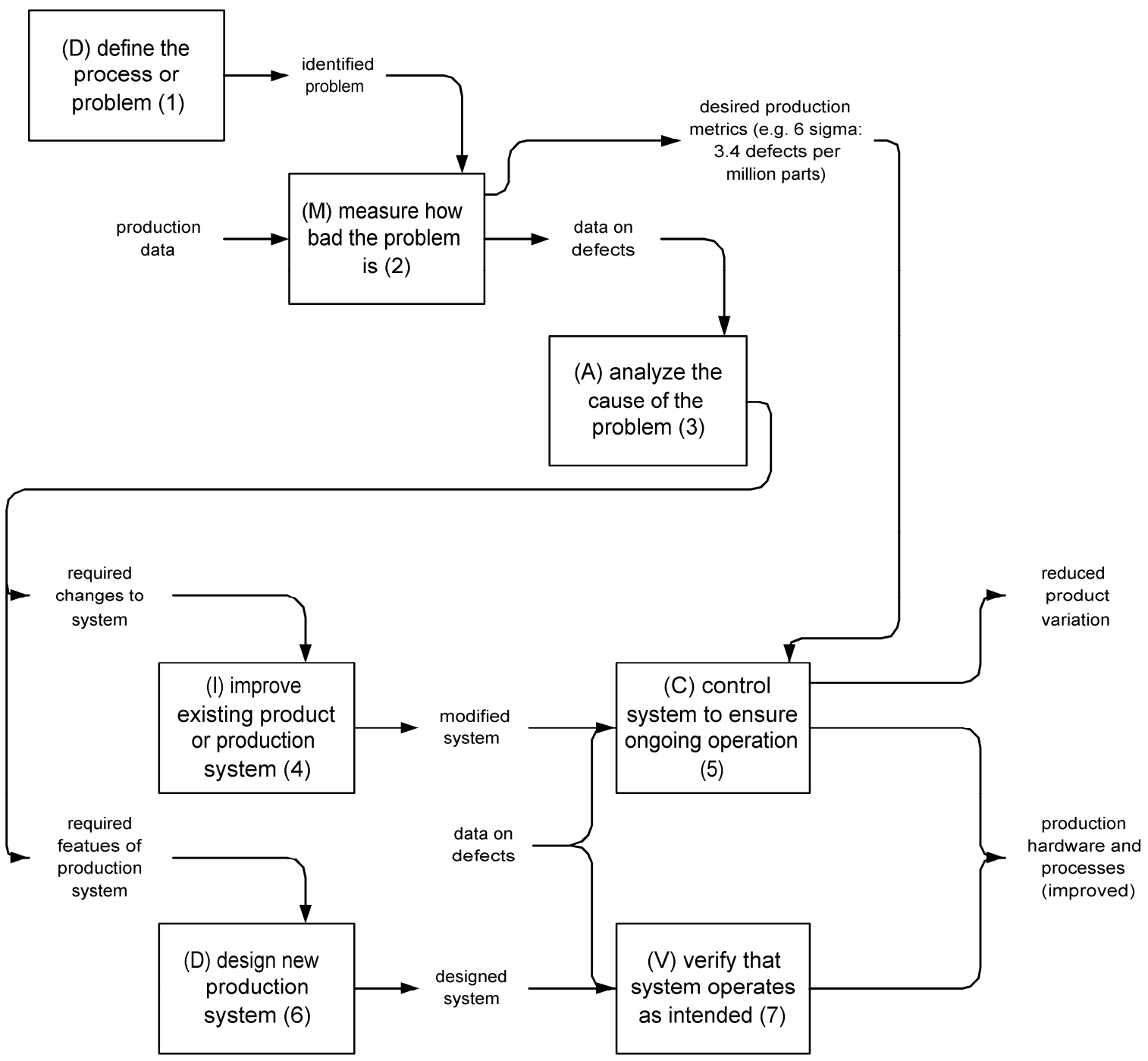




\section{$5 \quad$ Discussion}

Manufacturing organisations have the obvious constraint of needing to maximise their financial benefit. This is typically constrained by shareholder needs, required short-term yields (including arbitrary end-ofperiod production targets), and organisational financial viability. On its own, this objective results in production strategies of minimum cost and maximum product volume, i.e. the conventional continuous production process. However it has detriments, especially the risk of poor product quality, so it is not always sustainable. Consequently organisations often need to also include the strategy of maximising of customer benefit, typically using TQM and JIT. For longer-term sustainability it is necessary to also include elements of a strategy to maximise society benefit, particularly the benefit to the local community, but more generally the benefit to all people. This may be motivated by ethics (sensitivity to not harm others), government controls, inter/national identity, or a desire to improve worker satisfaction. The lean production methods are valuable as they can simultaneously provide elements of all these strategies.

Whether JIT and lean production are suitable for a given situation is partly determined socially. There is a requirement for commitment from everyone in the organisation and perhaps more emphasis on workers than managers (Keys, 1991). For successful implementation it appears also to be preferable that there be a high level of trust throughout the organisation, homogenous social culture, collectivistic society (cf. individualistic), lifetime employment in organisation (no job insecurity), and nationalistic society (government and bank financial commitment) (Keys, 1991). These are characteristics of Japanese society and may not replicate easily. For example, Japanese businesses have 'long-term trading relations among ... the main bank', major suppliers, subcontractors, distributors' (Yoshimori, 1995, p33), such that the bank will even intervene to run the business if it gets into trouble. From the technical perspective, successful JIT also requires repetitive manufacturing, low production setup times, an assembly schedule that is level and stable, and low product variability (i.e. standardised products) (Akturk \& Erhun, 1999). It is also preferable that discrete parts be supplied to an assembly line (i.e. not an assembly tree).

A systematic model of the inventory control systems within JIT and lean production has been demonstrated. This model has avoided quantitative simulation of the behaviour of a production system, but rather has identified the qualitative factors associated with failure or success of JIT, and proposed some descriptive relationships of causality. Benefits, limitations, and pre-conditions have been identified at multiple points within the diagrams. The model has provided some movement towards solving the problems identified by Corbett and Yucesan (Corbett \& Yucesan, 1993). It has examined environmental factors, and the reasons why JIT and lean systems succeed or fail.

The model described here was able to identify benefits, detriments, and pre-conditions of such production processes (particularly kanban) from multiple user perspectives, as summarised in Table 1. These factors are readily available from the diagrams by inspection, and are thus a natural consequence of the modelling strategy taken here. The diagrams themselves show important additional information about the proposed causality, i.e. the relationships between these factors and why they are important, which cannot be represented in the table.

\begin{tabular}{|c|c|c|c|}
\hline Perspective & Benefits & Detriments & Requirements for success \\
\hline Production control & $\begin{array}{l}\text { Kanban has low inventory of } \\
\text { finished product, and }\end{array}$ & $\begin{array}{l}\text { May be a disadvantage with some } \\
\text { distribution systems. Kanban }\end{array}$ & $\begin{array}{l}\text { Requires fast setup of machines, flexible } \\
\text { machines, mix of similar products, }\end{array}$ \\
\hline
\end{tabular}




\begin{tabular}{|c|c|c|c|}
\hline Perspective & Benefits & Detriments & Requirements for success \\
\hline & $\begin{array}{l}\text { relatively low inventory of } \\
\text { work in progress. }\end{array}$ & $\begin{array}{l}\text { requires a base level of inventory at } \\
\text { all times, and thus is not the leanest } \\
\text { control method possible. }\end{array}$ & repetitive manufacturing, \\
\hline Production control & $\begin{array}{l}\text { Minimal storage space, } \\
\text { minimal handling of parts. }\end{array}$ & $\begin{array}{l}\text { Fluctuating inventory, congestion in } \\
\text { production (bottlenecks). }\end{array}$ & Requires suitable plant layout. \\
\hline Production control & $\begin{array}{l}\text { Inventory in buffer protects } \\
\text { downstream stations, output } \\
\text { buffer will not exceed a set } \\
\text { limit. }\end{array}$ & $\begin{array}{l}\text { Kanban amplifies upstream } \\
\text { inventory variability. }\end{array}$ & $\begin{array}{l}\text { Requires assembly schedule that is level } \\
\text { and stable, and balanced production } \\
\text { machines. }\end{array}$ \\
\hline Production control & $\begin{array}{l}\text { Simple production control } \\
\text { system, does not require } \\
\text { extensive monitoring and } \\
\text { reporting as do some other } \\
\text { methods. }\end{array}$ & $\begin{array}{l}\text { Kanban may be cumbersome and } \\
\text { inefficient if there is an extensive } \\
\text { assembly tree. }\end{array}$ & $\begin{array}{l}\text { Prefers discrete parts supplied to an } \\
\text { assembly line. }\end{array}$ \\
\hline $\begin{array}{l}\text { Manufacturing } \\
\text { economics }\end{array}$ & $\begin{array}{l}\text { Reduced scrap and rework, } \\
\text { quantified measures of yield } \\
\text { and waste. }\end{array}$ & & $\begin{array}{l}\text { Requires effective and rapid detection } \\
\text { and resolution of defects and production } \\
\text { problems, quality assurance processes. }\end{array}$ \\
\hline Customer & $\begin{array}{llr}\text { Customer can } & \text { have } & \text { small } \\
\text { production } & \text { runs } & \text { of } \\
\text { standardised products. } & \end{array}$ & $\begin{array}{l}\text { Customer might need to wait for the } \\
\text { order to be fulfilled. Often requires } \\
\text { intermediate distributor to carry } \\
\text { stock. Sudden large orders not easy } \\
\text { to accommodate. }\end{array}$ & $\begin{array}{l}\text { Requires known customer buying } \\
\text { patterns and market demand (pull), } \\
\text { consistent demand and is at risk when } \\
\text { schedule fluctuates. }\end{array}$ \\
\hline Customer & $\begin{array}{l}\text { Customer may have a product } \\
\text { with a special configuration at } \\
\text { no extra financial cost, i.e. } \\
\text { offer custom configuration } \\
\text { within product family. }\end{array}$ & $\begin{array}{l}\text { Customer has some but limited } \\
\text { choice of product. }\end{array}$ & $\begin{array}{l}\text { Requires low product variability (i.e. } \\
\text { standardised product configurations). }\end{array}$ \\
\hline $\begin{array}{l}\text { Quality } \\
\text { improvements }\end{array}$ & $\begin{array}{l}\text { Improved quality of product. } \\
\text { Elicit suggestions for } \\
\text { improvement } \quad \text { from } \\
\text { productions staff. Solves } \\
\text { production problems fast. }\end{array}$ & & $\begin{array}{l}\text { Requires production and quality control } \\
\text { genuinely devolved to workers. }\end{array}$ \\
\hline Worker & Reduced effort or labour. & Reduced labour needs, retraining. & Needs staff with flexible skills. \\
\hline Worker & $\begin{array}{l}\text { Empowerment and job } \\
\text { satisfaction, motivation. }\end{array}$ & & $\begin{array}{l}\text { Requires that workers must accept } \\
\text { devolved responsibility with pride, } \\
\text { commitment from everyone in } \\
\text { organisation, more emphasis on workers } \\
\text { than managers, secure ongoing } \\
\text { workforce motivation, preferably high } \\
\text { trust throughout organisation. }\end{array}$ \\
\hline Supplier & & $\begin{array}{l}\text { Small orders or production runs may } \\
\text { be uneconomic for supplier. }\end{array}$ & $\begin{array}{l}\text { Requires industries grouped together, } \\
\text { alternatively in-house manufacture and } \\
\text { supply of parts, nearby and reliable } \\
\text { transport system, cluster of similar } \\
\text { industry for supplier to serve. Requires } \\
\text { social ethic of loyalty between } \\
\text { manufacturer and supplier. }\end{array}$ \\
\hline National & $\begin{array}{l}\text { Local community benefit, } \\
\text { employment, quality of life at }\end{array}$ & Potentially protected economy with & $\begin{array}{l}\text { Preferably a homogenous social culture, } \\
\text { collectivistic society (cf individualistic), }\end{array}$ \\
\hline
\end{tabular}




\begin{tabular}{|l|l|l|l|}
\hline Perspective & Benefits & Detriments & Requirements for success \\
\hline & work, reduced waste. & local stagnation. & $\begin{array}{l}\text { lifetime employment in organisation (no } \\
\text { job insecurity), supportive nationalistic } \\
\text { society (government and bank financial } \\
\text { commitment). }\end{array}$ \\
\hline
\end{tabular}

Table 1: Summary of benefits, detriments, and requirements for success for JIT kanban.

Importantly, the model is able to accommodate qualitative variables and high epistemic uncertainty (lack of knowledge of system relationships) (Pons \& Raine, 2004). The method is consistent with that mooted by Simon (Simon, 1981), namely the decomposition of a complex system into 'semi-independent components corresponding to its many functional parts' (p148). Again, as Simon observed, 'there is no reason to expect that the decomposition of the complete design into functional components will be unique' (p149), i.e. the model presented here is not expected to be the only valid perspective on control systems for JIT and lean production.

8

\section{Conclusions}

The primary consequence of JIT is reduction of inventory. The associated benefit is (a) improved cashflow due to less financial resource tied up in inventory, and (b) less storage space required hence more productive plant area. Coupled with lean production and other quality methods it is also possible to (c) improve worker productivity, (d) improve product quality, and (e) reduce production waste. Thus there are strong financial incentives to control inventory within production. However, the adoption of JIT and lean production methods is not uniform. Some manufacturing organisations have not attempted to adopt the new production methods, and others do but struggle to obtain the intended benefits (Teed, 2004).

Existing models of JIT and lean production are primarily either cases studies or mathematical simulation of system dynamics. Neither is particularly effective in identifying critical success factors for implementation, or the causality (Corbett \& Yucesan, 1993; Keys, 1991). While it is generally acknowledged that qualitative variables exist and affect success, there are no structured system models of JIT or lean that accommodate the qualitative variables, hence the need improvement in this area, albeit descriptive rather than mathematical models. This paper demonstrates that a descriptive model accommodating qualitative variables and subjective knowledge can indeed be developed for JIT/lean. The model goes beyond other flowchart models of the JIT and lean process in being able to not only list the factors but propose causality in a descriptive rather than mathematical manner. The expected application is the ability to include the qualitative success and risk factors in decision-making for organisations that are considering implementing JIT/lean production via inventory control, or are having difficulty gaining the expected advantages.

\section{A Appendix: Explanation of model}

Only some of the more complex parts of the model are elaborated here. 


\section{Produce product (Prd-2-1)}

Various production strategies optimise different characteristics of the plant. The common characteristics sought are maximised production volume or minimised transitional inventory. Five production strategies ( $A$ to $E$ ) are identified and described in the model. These are continuous, base stock, CONWIP, and kanban production, as well as hybrid strategies (Figures Prd-2-1 A to E). The generic activities, which are involved to various extents in each strategies, are setting a production schedule (4), a supplier providing precursor product (3), manufacture of parts for stock (5), production of intermediate product (2), assembly (1), and release of product to customer (7).

\section{Continuous production (Prd-2-1) A}

Continuous production is a strategy that drives the entire production from a production schedule that anticipates demand before it actually occurs. See Figure Prd-2-1A for flow of information, control and material through such a plant. The strategy seeks to maximise volume of production and therefore involves continuous production of parts, the intermediate storage of those parts, and their subsequent delivery to the assembly line. This ensures that the plant robustly operates at maximum production volume. It also maximises usage of capital equipment, and availability of product to customers. High customer service rates are thus possible, or low wait times. It is better in this regard than the other strategies. It is efficient at maximising the use of capital equipment. It is the historically conventional way for producing large volumes of product.

However this approach does have detriments, as listed in the figure. Prime among these are the risk of high wastage of defective parts, obsolete stock, low quality product, and poorly motivated staff. In the short term these detriments may have little effect on the financial viability of the organisation. However, they can be major impediments to long term viability, especially as this production strategy tends to also result in the inability to respond to new developments in the market (lack of flexibility of plant).

\section{Basestock production (Prd-2-1) B}

With basestock the production is controlled by the withdrawal of finished product by the customer, see Figure Prd-2-1B. As soon as withdrawal occurs, work orders are transmitted simultaneously to all production stages. This strategy is highly effective in minimising the amount of inventory in each output buffer, and thus it is a particularly lean strategy. It also results in smooth workflow throughout the plant. It is not particularly robust when there are line failures, since inventory accumulates (potentially unlimited) upstream of the line blockage. The strategy provides central control of production. However, with this comes the detriment of requiring a large number of work orders to administer centrally, although this is not necessarily a problem with an automated plant.

\section{Conwip production (Prd-2-1) C}

The constant-work-in-progress (conwip) strategy permits new raw material to enter production only when a finished product is removed, see Figure Prd-2-1C. The first machine in the process only starts work on a new part when a completed product has been removed from the store of finished goods. Thus conwip is also a JIT system. Work in progress is completed as soon as possible and passed downstream. Intermediate machines continue to work on parts when received, and do not need further authorisation. Consequently, the idle state of the plant has zero parts in intermediate buffers and a full store of finished 
goods (Bonvik, Couch, \& Gershwin, 1997; Bonvik \& Gershwin, 1996). Thus there can be even less inventory than in a kanban system (Bendell, 2006), so conwip also qualifies as a lean manufacturing approach. Conwip is an effective control strategy if the demand is unknown before it occurs (variable and unpredictable), whereas kanban is most effective if the demand is known beforehand. When demand is consistently high then internal buffers are all full and kanban and conwip show similar results.

Final service rate to the customer is good for conwip. The system has better characteristics than basestock when there are line disturbances. When the line fails downstream then the output buffer will fill to the set global maximum, and inventory will accumulate upstream of the blockage but only to a limit. However, the detriment of conwip is that all the points of entry of raw material have to be notified when a finished product is released to the customer, and this imposes an administrative cost.

\section{Kanban production (Prd-2-1) D}

Kanban control, see Figure Prd-2-1D, ensures that parts are only produced when specifically requested by a downstream process, hence 'just-in-time' (JIT). This strategy limits internal transitional inventory, hence is considered lean.

An assembly schedule (4) (configuration, quantity, timing) is provided to the assembly line, and the workers then build the associated products. A variety of product configurations may be built in a day. One of the most common implementations is to use a physical card (hence the Japanese word 'kanban'). The kanban specifies the number of parts, subassemblies or products to be produced. Production only occurs on receipt of the kanban, and even then only of the specified quantity. The parts and the kanban are then passed to the downstream process, and it only releases the kanban when the parts are consumed. Importantly, the number of kanbans in circulation is limited, and so this has the effect of limiting the amount of work in progress and thus transitory inventory. When a machine has completed its kanban assignment, then it and its operator may be diverted to another production task.

At the simplest level of implementation the kanban system only applies to the assembly line, and the production of parts and ordering from suppliers is done by a production schedule that produces parts for stock. This is called a single kanban system as there is only one kanban, the move kanban, (alternatively termed transportation, conveyance, or withdrawal kanban) that authorises the resupply of parts to the assembly line. A more comprehensive implementation extends kanbans to part production and material supply. Thus parts may be manufactured just-in-time (2), in which case the machines upstream of assembly only make parts when specifically instructed to do so, i.e. they do not make parts for stock, but only on receipt of a make kanban (alternatively production kanban). Similarly, vendors (3) may be required to supply batches of parts or raw materials only on receipt of a vendor kanban, rather than according to a set schedule. Delivery from suppliers can be simple (to warehouse) or integrated (direct to production line). An alternative to the above kanban based system is the 'two-bin' system, which has two containers of parts, so that one is always full. This provides a paperless control system.

The kanban system has the attractive feature of being simple and effective. It does not require extensive monitoring and reporting as do some other methods. It devolves short-term control of the production process to workers, hence improving empowerment and motivation. Potentially benefits are increased productivity, product quality, and incremental innovation. Thus it integrates well with many other quality mechanisms (such as quality circles and kaizen) which are likewise devolved to workers.

Kanban control requires known customer buying patterns and market demand (pull), and abhors the manufacture of product for stock (push). Kanban attempts to keep the output buffer full at each 
machine. Therefore, when a station fails the outputs will fill to set local maxima upstream of the line blockage. The tendency to have full output buffers means that kanban is not the leanest production strategy possible. Conwip is leaner as regards transitional inventory. Kanban does however have the advantage of low inventory of finished product, although this may be a disadvantage with some distribution systems, especially if the demand is unknown.

There are detriments to kanban, such as the need for consistent demand (it is at risk when the schedule fluctuates). It may be cumbersome and inefficient if there is an extensive assembly tree. It amplifies upstream inventory variability, i.e. the upstream workflow is not as smooth as other strategies.

\section{Hybrid production strategies (Prd-2-1) E}

Each of the above control strategies has merits and disadvantages, and a pure implementation may not always be practical. For example, pure kanban or conwip control systems respond sub-optimally to plant stoppage (e.g. machine unreliability). Some machines may be inefficient to start and stop (e.g. plastic injection molders), or take considerable set up time (e.g. sheet metal presses), or the raw material is supplied in large fixed quantities (e.g. whole sheets of steel). Thus many real production plants also deploy a strategy of manufacture of certain parts for stock. This is done on receipt of a schedule from a central planning department or on receipt of an instruction from a downstream machine. Likewise, many manufacturers have a central store of some parts, which is also contrary to the pure JIT philosophies.

The manufacture and storage of parts for subsequent consumption is readily integrated with other strategies, including kanban (Bonvik \& Gershwin, 1996). A model of this is shown in Figure Prd-2-1E.

\section{Produce intermediate product (Prd-2-1-2)}

The process for manufacturing intermediate products with kanban control is shown here. The perspective is that of one station in the line. The process starts when a move kanban arrives, resulting in parts being dispatched from the machine output buffer (4). Parts are never released without a move kanban. The parts are taken away with the move kanban, and this releases the make kanban that was formerly attached to the parts. This unfulfilled make kanban then initiates Activation of the production station (1), in which the machine is readied for the operation, the labour is assigned, and the raw materials or precursor part are requested from the upstream station (7) using a move kanban. When everything is available the parts are manufactured (2). These are then checked (3), preferably immediately to minimise the production of defective parts. For its success, the kanban system requires that machines only make parts when a free kanban appears, and that the machine only makes as many parts as the kanban states. Once made, the parts (inspected) are placed in their container along with the make kanban. The set is temporarily stored at the output buffer of the machine, waiting for the next move kanban to arrive from a downstream stations. Since the manufacturing activity stops when the mandated number of parts is made, the production worker is redeployed to a new task (5), as is the machine (6). This requires flexible machines and suitable layout, a mix of similar products, rapid changeover of tooling, and staff with flexible skills. Job rotation within a manufacturing cell is commonly used to develop staff flexibility. 


\section{Table captions}

Table 1: Summary of benefits, detriments, and requirements for success for JIT kanban.

\section{Figure captions}

Produce product/service (Prd)

Develop production capability (Prd-1)

Decide on a production strategy (Prd-1-3)

Set up production processes (Prd-1-4): Kanban example

Set up kanban system (Prd-1-4-3)

Test and commission system (Prd-1-5)

Operate the production system (Prd-2)

Produce product (Prd-2-1) A: Continuous

Produce product (Prd-2-1) B: Basestock

Produce product (Prd-2-1) C: Conwip

Produce product (Prd-2-1) D : Kanban

Produce product (Prd-2-1) E: Hybrid kanban + stock

Assemble final product (Prd-2-1-1): Kanban

Produce intermediate product (Prd-2-1-2): Kanban

Supplier provides precursor product (Prd-2-1-3): Kanban

Set production schedule (Prd-2-1-4): Kanban

Manufacture parts for stock (Prd-2-1-5)

Store and retrieve parts (Prd-2-1-6)

Continuously improve product quality (Prd-2-2)

Production worker checks output and corrects any problems (Prd-2-2-1)

Improve production processes (Prd-2-2-2): B Six Sigma method

\section{References}

Abdou, G., \& Dutta, S. P. (1993). Systematic simulation approach for the design of JIT manufacturing systems. Journal of Operations Management, 11(3), 225-238.

Ackoff, R. L. (1981). The art and science of mess management. Interfaces, 11(1), 20-26.

Akturk, M. S., \& Erhun, F. (1999). An overview of design and operational issues of kanban systems. International Journal of Production Research, 37(17), 3859-3881.

Alford, D., Sackett, P., \& Nelder, G. (2000). Mass customization - an automotive perspective. International Journal of Production Economics, 65(1), 99-110.

Anderson, J. W. (1985). JIT ORGANIZATION: A CASE STUDY. Paper presented at the APICS, Twenty-Eighth Annual International Conference Proceedings., Toronto, Ont, Can.

Aytug, H., Dogan, C., \& Bezmez, G. (1996). Determining the number of kanbans: A simulation metamodeling approach. Simulation, 67(1), 23-32.

Baird, M., \& Lansbury, R. D. (1998). Emerging production systems and industrial relations: Confusion, diffusion, and exclusion? Human Factors and Ergonomics In Manufacturing, 8(2), 141-153.

Bendell, T. (2006). A review and comparison of six sigma and the lean organisations. Consistency and Transformation in the Quality Movement

TQM Magazine, 18(3), 255-262.

Benjaafar, S. (2002). Modeling and analysis of congestion in the design of facility layouts. Management Science, 48(5), 679-704.

Black, J. (2007). Design rules for implementing the Toyota Production System. The Toyota Production System: Thirty Years of Research, and Beyond

International Journal of Production Research, 45(16), 3639-36641.

Bonvik, A. M., Couch, C., \& Gershwin, S. B. (1997). A Comparison of Production-Line Control Mechanisms. International Journal of Production Research, 35(3), 789-804. 
Bonvik, A. M., \& Gershwin, S. B. (1996). Beyond Kanban: Creating and analyzing lean shop floor control policies. Paper presented at the Manufacturing and Service Operations Management Conference Proceedings, Dartmouth College, The Amos Tuck School, Hanover, New Hampshire.

Callen, J. L., Fader, C., \& Krinsky, I. (2000). Just-in-time: A cross-sectional plant analysis. International Journal of Production Economics, 63(3), 277-301.

Caridi, M., \& Sianesi, A. (2000). Multi-Agent Systems in production planning and control: An application to the scheduling of mixed-model assembly lines. International Journal of Production Economics, 68(1), 29-42.

Corbett, C., \& Yucesan, E. (1993). Modeling just-in-time production systems: a critical review. Paper presented at the Proceedings of the 1993 Winter Simulation Conference.

Detty, R. B., \& Yingling, J. C. (2000). Quantifying benefits of conversion to lean manufacturing with discrete event simulation: A case study. International Journal of Production Research, 38(2), 429-445.

FIPS. (1993). Integration Definition for Function Modeling (IDEFO). Retrieved 12 Aug 2003, from http://www.itl.nist.gov/fipspubs/idef02.doc

Fukukawa, T., \& Hong, S.-C. (1993). The determination of the optimal number of kanbans in a just-in-time production system. Computers \& Industrial Engineering, 24(4), 551-559.

Genaidy, A. M., \& Karwowski, W. (2003). Human performance in lean production environment: Critical assessment and research framework. Human Factors and Ergonomics In Manufacturing, 13(4), 317-330.

Gingele, J., Childe, S. J., \& Miles, M. E. (2003). Incorporating links to ISO 9001 into manufacturing process models using IDEF9000. International Journal of Production Research, 41(13), 3091-3118.

Golhar, D. Y., \& Sarker, B. R. (1992). Economic manufacturing quantity in a just-in-time delivery system. International Journal of Production Research, 30(5), 961-972.

Hajela, P., \& Vittal, S. (2006). Optimal design in the presence of modeling uncertainties. Journal of Aerospace Engineering, 19(4), 204-216.

Herron, C., \& Braiden, P. M. (2006). A methodology for developing sustainable quantifiable productivity improvement in manufacturing companies. International Journal of Production Economics, (Strategic Issues and Innovation in Production Economics), 104(1), 143-153.

Holweg, M. (2007). The genealogy of lean production. Special Issue Evolution of the Field of Operations Management SI/Special Issue Organisation Theory and Supply Chain Management

Journal of Operations Management, 25(2), 420-437.

Houshmand, M., \& Jamshidnezhad, B. (2006). An extended model of design process of lean production systems by means of process variables. Robotics and Computer-Integrated Manufacturing, 22(1), 1-16.

Hu, A. B., \& Meerkov, S. M. (2006). Lean buffering in serial production lines with Bernoulli machines. Mathematical Problems in Engineering, 2006, 17105.

Huang, C.-C., \& Kusiak, A. (1998). Manufacturing control with a push-pull approach. International Journal of Production Research, 36(1), 251-275.

Kaipia, R., Holmstrom, J., \& Tanskanen, K. (2002). VMI: What are you losing if you let your customer place orders? Production Planning and Control, 13(1), 17-25.

KBSI. (2000). IDEFO Overview. Retrieved 12 Aug 2003, from http://www.idef.com/idefO.html

Keys, D. E. (1991). Five Critical Barriers to Successful Implementation of JIT and Total Quality Control. Paper presented at the Industrial Engineering Research - Conference Proceedings May 24-25.

Koh, S. C. L., Demirbag, M., Bayraktar, E., Tatoglu, E., \& Zaim, S. (2007). The impact of supply chain management practices on performance of SMEs. Industrial Management and Data Systems, 107(1), 103-124.

Leclair, E. (2005). Just-in-time? Not so fast. Design Engineering (Toronto), 51(2), 24-25.

Lee, B.-H., \& Jo, H.-J. (2007). The mutation of the Toyota Production System: Adapting the TPS at Hyundai Motor Company. The Toyota Production System: Thirty Years of Research, and Beyond

International Journal of Production Research, 45(16), 3665-3679.

Leinonen, J. I. (1993). Impact of manufacturing technology and production philosophies on work-in-process inventory levels

Proceedings of the IFIP TC5/WG5.7 5th International Conference on Advances in Production Management Systems - APMS'93, Sep 28-30 1993. In (pp. 357-362). Athens, Greece: Publ by Elsevier Science Publishers B.V., Amsterdam, Neth.

Lian, Y.-H., \& Van Landeghem, H. (2007). Analysing the effects of Lean manufacturing using a value stream mapping-based simulation generator. International Journal of Production Research, 45(13), 3037-3058.

Mehta, V. B., \& Shah, H. K. (2005). Characteristics of a work organization from a lean perspective. EMJ - Engineering Management Journal, 17(2), 14-20.

Mistry, J. J. (2005). Origins of profitability through JIT processes in the supply chain. Industrial Management and Data Systems, 105(6), 752-768.

Naim, M. M., Childerhouse, P., Disney, S. M., \& Towill, D. R. (2002). A supply chain diagnostic methodology: Determining the vector of change. Computers and Industrial Engineering, 43(1-2), 135-157.

Plenert, G., \& Best, T. D. (1986). MRP, JIT, and OPT: What's "Best"? Production And Inventory Management, 27(2), 22-30. 
Pons, D. J., \& Raine, J. (2004). Design with uncertain qualitative variables under imperfect knowledge. Journal of Engineering Manufacture, 218(8), 977-986.

$\begin{array}{lllll}\text { SAP. } & \text { (2004). } & \text { KANBAN } & \text { Scenario } & \text { (Collaborative). }\end{array}$ http://www50.sap.com/businessmaps/8B0EOA41DA8946C29F7BF1ED336F7093.htm.

Schroer, B. J. (2004). Simulation as a tool in understanding the concepts of lean manufacturing. Simulation, 80(3), 171-175.

Schultz, K., Juran, D., Boudreau, J., McClain, J., \& Thomas, L. J. (1996). Work group performance in lean manufacturing systems: Which WIP worries workers? Paper presented at the Proceedings of the 1996 27th Annual Meeting of the Decision Sciences Institute. Part 2 (of 3), Nov 24-26 1996, Orlando, FL, USA.

Selvaraj, N., Rao, C. S. P., \& Janardhan Reddy, T. A. (2003, Jul 2-4 2003,). Simulation of machine breakdowns in a pull production system operated by various control mechanisms. Paper presented at the Proceedings of the IASTED International Conference on Modelling, Simulation and Optimatization, Banff, Alta., Canada.

Shah, R., \& Ward, P. T. (2003). Lean manufacturing: Context, practice bundles, and performance. Journal of Operations Management, 21(2), 129-149.

Simon, H. A. (1981). The sciences of the artificial (2 ed.). Massachusetts: The MIT Press,.

Soriano-Meier, H., \& Forrester, P. L. (2002). A model for evaluating the degree of leanness of manufacturing firms. Integrated Manufacturing Systems, 13(2), 104-109.

Teed, N. (2004). Achieving the lean dream. http://www.advancedmanufacturing.com/March01/leanmanuf.htm.

Tyler, D. F., \& Cathcart, T. P. (2006). A structured method for developing agile enterprise architectures. International Journal of Agile Manufacturing, 9(2), 73-82.

Walsh, K. D., Sawhney, A., \& Bashford, H. H. (2007). Production equations for unsteady-state construction processes. Journal of Construction Engineering and Management, 133(3), 254-261.

White, A. S. (1999). Management of inventory using control theory. International Journal of Technology Management, 17(7-8), 847-860.

Yoshimori, M. (1995). Whose company is it? The concept of the corporation in Japan and the West. Long Range Planning, 28(4), 33-44.

Zapfel, G. (1998). Customer-order-driven production: An economical concept for responding to demand uncertainty? Proceedings of the 1996 9th International Working Seminar on Production Economics, Feb 19-23 1996 International Journal of Production Economics, 56-57, 699-709. 